ISSN 2587-8123 (Print) ISSN 2658-5995 (Online)

МИНИСТЕРСТВО НАУКИ И ВЫСШЕГО ОБРАЗОВАНИЯ РОССИЙСКОЙ ФЕДЕРАЦИИ ВОЛГОГРАДСКИЙ ГОСУДАРСТВЕННЫЙ УНИВЕРСИТЕТ

НИЖНЕВОЛЖСКИЙ АРХЕОЛОГИЧЕСКИЙ ВЕСТНИК 2021 Tом 20. № 2

MINISTRY OF SCIENCE AND HIGHER EDUCATION OF THE RUSSIAN FEDERATION VOLGOGRAD STATE UNIVERSITY

THE LOWER VOLGA ARCHAEOLOGICAL BULLETIN 2021 Volume 20. No. 2

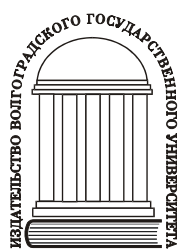




\section{СОДЕРЖАНИЕ}

Конец прекрасной эпохи (Редакциионная коллегия) .... 5

\section{СТАТЬИ}

Файзуллин И.А., Купцова Л.В., Мухаметдинов В.И. Гончарное производство срубной культуры Предуралья по материалам курганного могильника I у села Твердилово

Балабанова М.А., Клепиков В.М., Перерва Е.В. Погребальный обряд и морфология погребенного из кургана могильника Тау (Западный Казахстан) .... 24

Монахов С.Ю. Типология и хронология аканфских амфор [На англ. яз.] 43

Абрамова А.Н. Население Прикубанья раннего железного века по данным краниофенетики (предварительные данные) .66

Малашев В.Ю., Маслов В.Е. Курганы-кладбища центральных и восточных районов Северного Кавказа III в. до н.э. - начала (первой половины) II в. н.э. (памятники типа Чегем-Манаскент)

Ковалева К.С. Производственные

бронзолитейные комплексы

городов Золотой Орды: поиск аналогий

Дрёмов И.И., Круглов Е.В. Железные конусы в погребениях Улуса Джучи:

аспекты этнокультурной принадлежности 149

Гаглойты Р.Х., Кочкаров У.Ю., Мамаев Р.Х., Нарожный В.Е., Нарожный Е.И. Наконечники копий келийского каменноящечного могильника (Горная Ингушетия)

\section{ПУБЛИКАЦИИ}

Кривочеев М.В., Моисеев В.И.

Погребения раннесарматского времени

с территории Чеченской Республики

Иванов С.С. Редкая поясная бляха

в зооморфном стиле с Внутреннего Тянь-Шаня..... 196

Николаев С.Ю. Три сарматских кинжала

с подножия горы Торатау 204

\section{НАУЧНАЯ ЖИЗНЬ}

Итоги VI Нижневолжской Международной археологической научной конференции «Волго-Уральский регион от древности до Средневековья» (Оргкомитет конферениии) 214

\section{CONTENTS}

The End of a Great Era (Editorial Staff) 5

\section{ARTICLES}

Fayzullin I.A., Kuptsova L.V., Mukhametdinov V.I. The Ceramics Production of the Cis-Ural Srubnaya Culture: A Case Study of the Kurgan Cemetery I Near Tverdilovo Village ..... 8

Balabanova M.A., Klepikov V.M., Pererva E.V. Funeral Rite and Morphology of a Buried Man from Kurgan of Tau Cemetery (Western Kazakhstan) .... 24 Monakhov S.Yu. Typology and Chronology of Akanthian Amphorae

Abramova A.N. Craniophenetic Features

of Cis-Kuban Population of the Early Iron Age (Preliminary Data)

Malashev V.Yu., Maslov V.E. Kurgan-Cemeteries of Central and Eastern Regions of North Caucasus $3^{\text {rd }}$ Century BC - Early $2^{\text {nd }}$ Century AD

(Monuments Chegem-Manaskent Type)

Kovaleva K.S. Manufacturing Complexes for the Non-Ferrous Metals Processing of the Golden Horde Cities: Search for Analogies

Dremov I.I., Kruglov E.V. Iron Cones

in the Burials of Ulus Jochi:

Aspects of Ethnocultural Identification

Gagloiti R.H., Kochkarov U.U., Mamaev R.Kh., Narozhnyi V.E., Narozhnyi E.I. Spearheads of the Keliysky Stone Box Burial Ground (Ingushetia Highlands)

\section{PUBLICATIONS}

Krivosheev M.V., Moiseev V.I.

Early Sarmatian Burials

from the Chechen Republic Territory

Ivanov S.S. A Rare Belt Plaque in Zoomorphic Style from the Inner Tien Shan.... 196

Nikolaev S.Yu. Three Sarmatian Daggers

from the Foot of Toratau Mount

\section{SCIENTIFIC LIFE}

Proceedings of the $6^{\text {th }}$ Lower Volga International Scientific Conference on Archaeology

"The Volga-Ural Region -

from Antiquity to the Middle Ages"

(Organizing Committee of the Conference) 214 


\title{
IRON CONES IN THE BURIALS OF ULUS JOCHI: ASPECTS OF ETHNOCULTURAL IDENTIFICATION ${ }^{1}$
}

Submitted: 13.06 .2021

Accepted: 30.10 .2021

\author{
Igor I. Dremov
}

Regional Center for Ecology, Local Studies and Tourism, Saratov, Russian Federation

\section{Evgeniy V. Kruglov}

Volgograd Regional Branch of the All-Russian Society for Protection of Monuments of History and Culture, Volgograd, Russian Federation

\begin{abstract}
Cone-shaped objects, rolled from iron and bronze sheets, are found in the Golden Horde burials of the late $13^{\text {th }}$ - early $15^{\text {th }}$ centuries. The authors collected information on more than 100 burials with iron and bronze cones located in the territory of Ulus Jochi. This article is examines material from 78 iron cone burials. Specific features of the topographic location of these complexes, use of stones in rituals, construction of log cabins around graves is similar to archaeological and ethnographic monuments of Central Asia associated with ethnic Mongols. As a rule, human remains buried in graves are oriented north or northeast with their heads, which is also a feature of the Mongol funeral rite. Accompaniment of the burial with whole or stuffed horses remains in the complexes with cones is not common, but these features are also known in Mongolian cemeteries in Central Asia. The placement of a sheep tibia at the head of the buried occasionally in vertical position is considered a main ethnic feature of the Mongol culture. In general, the sample of the Ulus Jochi burials, united by the iron cones presence in the burial inventory, is characterized by an increased concentration of rather specific ritual signs typical of the Mongols of Central Asia. This allows us to conclude that the considered monuments belong to the same ethnocultural group of population. Moreover, the available anthropological data testify to the Central Asian (Mongolian) origin of the representatives of this group of nomads of Ulus Jochi Burials with iron cones. The authors observe manifestations of pagan shamanic and Buddhist rituals judging by the dominant features of funeral rituals left by the bearers of Mongolian ethnic and cultural traditions.
\end{abstract}

Key words: cones, funeral rite, nomads, Ulus Jochi, graves structures, sheep bones, northern orientation, Mongols.

Citation. Dremov I.I., Kruglov E.V., 2021. Zheleznye konusy v pogrebeniyah Ulusa Dzhuchi: aspekty etnokul'turnoy prinadlezhnosti [Iron Cones in the Burials of Ulus Jochi: Aspects of Ethnocultural Identification]. Nizhnevolzhskiy Arkheologicheskiy Vestnik [The Lower Volga Archaeological Bulletin], vol. 20, no. 2, pp. 149-168. DOI: https://doi.org/10.15688/nav.jvolsu.2021.2.7

УДК 902(653):39(=512.3)

ББК $63.444(235.54)+63.521(=64)$

Дата поступления статьи: 13.06.2021

Дата принятия статьи: 30.10 .2021

\section{ЖЕЛЕЗНЫЕ КОНУСЫ В ПОГРЕБЕНИЯХ УЛУСА ДЖУЧИ: АСПЕКТЫ ЭТНОКУЛЬТУРНОЙ ПРИНАДЛЕЖНОСТИ ${ }^{1}$}

\author{
Игорь Иванович Дрёмов \\ Областной центр экологии, краеведения и туризма, г. Саратов, Российская Федерация
}

\section{Евгений Викторович Круглов}

Волгоградское региональное отделение «Всероссийского общества охраны памятников истории и культуры», г. Волгоград, Российская Федерация

Аннотация. Конусовидные предметы, свернутые из листов железа и бронзы, встречаются в золотоордынских захоронениях 2-й половины XIII - начала XV века. В настоящее время это наименее изученная категория погре- 
бального инвентаря. Авторы собрали сведения более чем о 100 погребениях с железными и бронзовыми конусами, расположенных на территории Улуса Джучи. Данная статья основана на материалах 78 погребений с железными конусами. Специфические особенности топографического расположения этих комплексов, использование камня в ритуальной обрядности, сооружение вокруг могил бревенчатых срубов - все это находит прямые аналогии в археологических и этнографических памятниках Центральной Азии, связываемых с этническими монголами. Погребенные в могилах, как правило, ориентированы головами на север - северо-восток, что также былохарактерной особенностью погребального обряда монголов. Сопровождение погребенных останками целых лошадей или их чучелами в комплексах с конусами встречается не часто, но и эти особенности известны в монгольских могильниках Центральной Азии. Размещение у головы погребенных берцовой кости овцы, в том числе установленной вертикально, считается одним из основных этнических признаков погребального обряда монголов. В целом выборка захоронений Улуса Джучи, объединенных фактом наличия в погребальном инвентаре железных конусов, характеризуется повышенной концентрацией достаточно специфических обрядовых признаков, свойственных монголам Центральной Азии. Это позволяет сделать вывод о принадлежности рассматриваемых памятников к той же этнокультурной группе населения. О центральноазиатском (монгольском) происхождении представителейэтой группы кочевников Улуса Джучи свидетельствуют и имеющиеся антропологические данные. Захоронения с железными конусами, судя по доминантным признакам погребальной обрядности, оставлены носителями монгольских этнокультурных традиций с проявлениями языческих шаманских и буддийских ритуалов.

Ключевые слова: конусы, погребальный обряд, кочевники, Улус Джучи, надмогильные конструкции, кости овцы, ориентировка на север, монголы.

Цитирование. Дрёмов И. И., Круглов Е. В., 2021. Железные конусы в погребениях Улуса Джучи: аспекты этнокультурной принадлежности // Нижневолжский археологический вестник. Т. 20, № 2. С. 149-168. DOI: https://doi.org/10.15688/nav.jvolsu.2021.2.7

Конусы в могилах кочевников Улуса Джучи являются одной из самых загадочных, а на данный момент - наименее изученной категорией погребального инвентаря. Они представляют собой небольшие предметы, свернутые из листа железа или бронзы; имеют высоту, как правило, от 2 до 6 см, но изредка бывают и крупнее. Данные изделия имеют разные пропорции, острую, скругленную или срезанную вершину; замкнутые, разомкнутые или стянутые внахлест края. Авторы раскопок и публикаций называют их поразному: конусы, колпачки, ворворки, колокольчики, шишаки, втоки для древок копий, стрекала, детали бунчуков и т. д. Соответственно, различны и мнения о предназначении этих изделий. Чаще всего их относят к предметам вооружения, украшениям сбруи, элементам головных уборов, деталям светильников, атрибутам культа. В погребениях чаще всего встречается по одному экземпляру, но есть и по несколько - до 8 [Дрёмов, 2019].

В классическом труде Г.А. ФёдороваДавыдова конусы только упоминались [Фёдоров-Давыдов, 1966, с. 87]. Тринадцать наиболее крупных предметов Т.М. Потёмкина включила в состав посудовидных изделий [Потёмкина, 2012]. Е.П. Мыськов, изучив конусы из 27 погребений Нижнего Поволжья, рассмотрел их в качестве самостоятельной катего- рии инвентаря [Мыськов, 2015, с. 227-228]. Авторами выявлено более ста погребальных комплексов с конусами, в том числе - 78 могил с железными (рис. 1) и около 30 захоронений с бронзовыми ${ }^{2}$. Эти материалы, сведенные в иллюстративные таблицы с указанием источника сведений, будут представлены в отдельной работе.

Задачей данной статьи является попытка определения этнокультурной принадлежности комплексов с железными конусами.

Хронология памятников решалась на основе системы, разработанной Г.А. Фёдоровым-Давыдовым. Все выявленные комплексы с железными конусами так или иначе относятся к IV хронологическому периоду кочевнических древностей Восточной Европы (вторая половина XIII - XIV в.) [Фёдоров-Давыдов, 1966, c. 93-116]. Данное обстоятельство подтверждает наличие в 10 памятниках монет, время выпуска которых укладывается от 1260/1277 до 1370/1380 г. (табл. 1). Помимо этого, погребение 1 кургана 2 из Карасуыра (рис. 3,I) датировано 1270-1320 гг. по $\mathrm{C}^{14}$ (более узкая калиброванная дата 1270-1300 гг.) [Усманова и др., 2020, с. 189-190]. Два комплекса имели датировки, основанные на стратиграфических наблюдениях. Погребение 9 из Азака, ул. Красноармейская, 56, прорезавшее слой времени начала существования этого городища и пере- 
крытое слоем с более поздними находками, относится к первой половине XIV века. Датировку по стратиграфическим данным, вторая половина XIV в. - начало XV в., имеет и погребение 4 из Болгара, восточный въезд: захоронения могильника прорезали слой и жилище первой половины XIV в. и были перекрыты грунтом с вала, разрушенного в 1430 г. [Газимзянов, Дрёмов, 2020].

Ареал распространения комплексов с железными конусами покрывает почти всю территорию Улуса Джучи: от междуречья Днестра и Южного Буга на западе до Центрального Казахстана на востоке и от Северного Кавказа до Булгара. Наибольшая концентрация памятников отмечена в Волго-Донском междуречье, на Нижнем Дону и в Нижнем Поднепровье (рис. 1).

Большинство комплексов с железными конусами происходит из курганов с обычными земляными насыпями, в которых преобладают основные захоронения. Могильники обычно состоят из нескольких небольших курганов высотой до 1 м. Более крупные насыпи единичны. В нескольких случаях погребения оформлялись надмогильными набросками из камня. Впускные захоронения в курганы предшествующих периодов встречаются редко. Погребение 1 кургана 7 могильника Хмелевой I было впущено в небольшой естественный бугор. Конусы также встречаются и в грунтовых (безкурганных) могилах. Вышеупомянутые захоронения из Азака и Болгара исследованы в могильниках, расположенных на территории крупных городских центров Золотой Орды. Погребенные были обращены головами на север - северо-восток и резко отличались от обычных безынвентарных могил, традиционно ориентированных на запад - юго-запад. Одиночный комплекс в Саратове на Вишнёвой горе обнаружен в 13 км от золотоордынского города Укек. Одиночное погребение из Маляевки выявлено на краю группы курганов, расположенных вблизи Царевского городища. Одно погребение зафиксировано в могильнике Мамай-Горы на Днепре, а еще три - у г. Евпатория (оз. Сасык). Один комплекс с конусом представлял собой кирпичный мавзолей.

Топография памятников. Выявленные памятники с конусами обычно располагались на склонах водоразделов, на локаль- ных возвышенностях и мысах. Иногда их находили в низинах или ложбинах. Одиночное захоронение близ Саратова выявлено в аллювиальных отложениях под северным склоном горы Вишневой, рядом с родником и спадающей с вершины ложбиной. Погребение 1 кургана 2 из Карасуыра располагалось в горах Улытау (Центральный Казахстан) в небольшой ложбине на северном склоне сопки. Погребение 1 кургана 2 из Шебалино располагалось в низине рядом с луговиной, заливаемой p. Мышкова, левым притоком Дона. Подобная топография типична для могильников Монголии и Тянь-Шаня, которые, «как правило, располагаются на возвышенностях, горных грядах, склонах и вершинах гор» [Акматов, Табалдиев, 2017, с. 71]. Распространенный у монголов обычай хоронить «на теневой стороне горы» (на северном склоне) отмечал в письменных источниках В.В. Бартольд [Бартольд, 1966, с. 391]. Особенность сооружения погребений в ложбинах, иногда расположенных на склонах гор или водоразделов, находит прямые аналогии именно в монгольских могильниках Центральной Азии [Именохоев, 1992, с. 34-48], этнографических материалах монголоязычных ойратов и у калмыков. Так, П.А. Смирнов в XIX в. отмечал, что для калмыцких захоронений выбирались места рядом с сезонным расположением хотона, как правило в небольшой впадине или неглубокой балке [Смирнов, 1999, с. 117]. Захчины (одна из групп ойратов Западной Монголии) для своих захоронений выбирали «большую и раздольную ложбину, где свободно могли бы разместиться все пять видов домашнего скота» [Мэнэс, 1992, с. 116]. Т.И. Шараева отмечает, что эта традиция отражает представление о загробном мире как о новом кочевье, что подтверждается наименованием места захоронения: «нутаг сонгох» - «выбирать кочевье» [Шараева, 2011, с. 169].

Бревенчатые сооружения, окружавшие некоторые могилы с конусами, представлены прямоугольными и многоугольными срубами. В кургане 3 из Миновки XVII над основной могилой 2 с северо-восточной ориентировкой погребенного была зафиксирована выровненная площадка с выложенной на ней прямоугольной срубной оградкой из бревен $6,0 \times 3,5$ м. Поверхность внутри оградки по- 
крывал слой тростника. В могиле вместе с железным конусом были стандартные предметы конской сбруи и воинского снаряжения, остатки шелковой ткани, бронзовый стаканчик и серебряные монеты. За колодой в изголовье располагалась кость конечности овцы (барана) (рис. 2,III) [Шалобудов, Кудрявцева, 1980]. В Кривой Луке XVI, курган 5, потревоженную могилу с останками погребенного, ориентированного головой на север, окружали бревна восьмиугольного сруба, поставленного на древнем горизонте (рис. 2,I). Вход в данное сооружение находился с северной стороны могилы. С этой же стороны располагались разрыв ровика и пустая яма, вероятно ритуальная. Материалы данного комплекса позволили Г.А. Фёдорову-Давыдову сделать авторитетный вывод о связи практики северных ориентировок с культом юга, так как «покойник должен был смотреть на полуденное солнце, то есть на юг». Резкое количественное возрастание в золотоордынское время в Нижнем Поволжье могил с ориентировками погребенных на север исследователь объяснил перемещением населения с востока. «Видимо, сибирские племена, хоронившие своих мертвецов головой на север, переселились в степи Восточной Европы, но быстро там рассредоточились» [Фёдоров-Давыдов, 1984].

Бревенчатые сооружения, окружавшие ряд золотоордынских погребений Волго-Донского региона, рассматривались также Е.П. Мыськовым. В качестве этнографических аналогий данным постройкам исследователь указал на многогранные срубные юрты Алтая, являвшиеся «привилегией зажиточных семей» [Мыськов, 2015, с. 17].

Пожалуй, наиболее показательным памятником является исследованный в 2017 г. курган 1 могильника Клин I. Под насыпью здесь был зафиксирован разобранный деревянный прямоугольный сруб, ориентированный по линии ССВ - ЮЮЗ. Внутри внешнего сруба заметны бревна внутреннего сруба (рис. 2,II). Внутри срубов были обнаружены две могилыкенотафа с гробами и инвентарем. В составе инвентаря погребения 2 зафиксирован железный конус с органическим тленом, фрагменты серебряной чаши с изображением лотоса, бронзовый казан с ковшом внутри, колчан и другой инвентарь [Курганный могильник Клин I].
Данные срубные постройки находят себе прямые аналогии в этнографических материалах Монголии, где подобные сооружения ставили над захоронениями нойонов, правителей областей. Такие могилы, украшенные деревянными моделями субурганов и остатками провалившихся срубов, в 1925 г. в горах Монголии видел П.К. Козлов [Козлов, 1949, с. 114]. В 1985 г. Н.Л. Жуковская исследовала в Монголии некрополь XVIII-XIX вв., в котором были похоронены пять нойонов. Он располагался на вершине горы и состоял из пяти срубных построек размерами около 2 м по сторонам и в высоту. «Каждый сруб (бухман) представлял собой глухую постройку, без окон и дверей. В двух были видны внутренние срубы меньшего размера, в них находятся остатки саркофагов... Фундаментом каждого сруба служила платформа из наваленных грудой камней...». Некоторые сооружения имели два сруба - один в другом, другие - один. Над одним из них посередине коньковой балки сохранился ганджир - навершие в виде цилиндра, увенчанного куполом, один из характерных признаков буддийских культовых построек. С южной стороны кладбища совершали жертвоприношения: жгли можжевельник, ставили «белую пищу» (молоко, масло, молочную водку, сыр и др.) [Жуковская, 1989, с. 165-170].

Использование камня в обрядности комплексов с конусами фиксируется неоднократно. Над погребением 1 кургана 5 могильника Русский Колодец VII была сооружена каменная площадка. В погребении 1 кургана 2 Карасуыра (рис. 3,I); погребении 1 кургана 4 Ковалёвки (рис. 3,II); погребении 1 кургана 41 Нововасильевки (Коминтерн); погребении 1 кургана 7 Русского Колодца VII и в погребении 3 Мамай-Горы IV над могилами находились наброски из камней. Погребение 1 из кургана 1 могильника Северный II было выявлено по наличию на дневной поверхности крупных камней. Камень, провалившийся в могилу, зафиксирован и в Клину I, курган 1, погребение 1. Отмечены камни в заполнении ям и в комплексах могильника Русский Колодец VII, курган 5, погребение 1; курган 7, погребение 2; курган 10, погребение 1; курган 11, погребение 1, а в погребении 2 кургана 10 могильника Власовский I они были встречены на дне ямы [Ковпаненко и др., 
2005; Курганный могильник Клин I; Усманова и др., 2020].

Использование камня традиционно считается одним из составляющих обрядовых признаков половецких погребений или же их наследием [Плетнёва, 1958, с. 179; 1962, с. 133; Фёдоров-Давыдов, 1966, с. 145]. Сравнительно недавно В.А. Иванов заметил, что каменные конструкции золотоордынских курганов и памятников Монголии, Забайкалья и ТяньШаня обнаруживают не просто аналогии друг другу, а практически полную идентичность. По его подсчетам, на территории Улуса Джучи от Иртыша до Дуная количество погребений с камнем составляет $18,4 \%$ от общего числа кочевнических могил [Иванов, 2019, с. 645]. Однако в Волго-Донском междуречье таких памятников лишь $0,2 \%$, а большая их часть, $10,7 \%$, находится в районах к востоку от Волги, где половцев не было. Уже это позволяет пересмотреть традиционное представление о камне как исключительно половецкой принадлежности. Полагаем, что в обрядности кочевников Улуса Джучи использование камня следует считать проявлением не только тюркокыпчакских (половецких), но и монгольских традиций. Также очевидно, что в Восточной Европе в золотоордынское время использование камня в погребальной обрядности зависело от конкретных особенностей той или иной местности. В Северном Причерноморье, на Южном Урале и на территории Казахского мелкосопочника (Сары-Арка) таких памятников больше, чем в степях Нижнего Поволжья, на значительной части которого вообще нет выходов камня на поверхность.

Огненные ритуалы в курганах с погребениями с конусами встречаются не часто, но они вариативны и показательны. В кургане 3 могильника Миновка XVII бревенчатая оградка основного погребения 2 была слегка обожжена (рис. 2,III). В одиночном кургане из Песковки рядом с могилой была площадка из обожженных комьев земли, перенесенных из мощного кострища со стороны. В Рыбинке, курган 1, погребение 1, под насыпью к северу от могилы зафиксирована площадка с углями и тремя обгорелыми бревнами. В Кировском V, курган 4, большое кострище выявлено над могилой погребения 1. В Сенном, курган 5, зафиксировано мощное кострище с прокалом земли и углями. Кострище с обугленными зернами злаковых культур и костями МРС прослежено к югу от сруба из погребения 1 кургана 1 из Клина I (рис. 2,II) [Шалобудов, Кудрявцева, 1980, с. 91; Мамонтов, Ситников, 1998, с. 115; Курганный могильник Клин I]. Все это также находит прямые соответствия в монгольских обрядах и ритуалах очищения огнем, хорошо известных, в частности, по описаниям истории русского князя Михаила Черниговского, казненного за отказ поклониться огню перед входом в шатер хана Бату. Этот исторический эпизод В.В. Бартольд приводил как пример обязательности исполнения культа почитания огня и южной стороны в Монгольской империи [Бартольд, 1966, с. 390, 392-394]. У калмыков обряд поклонения огню, согласно канонам, может проводиться только мужчинами в определенное время и в определенном месте, например через 7, 49 дней и через год после похорон. У калмыков-буддистов огонь считается средством очищения, поэтому после похорон люди не имели права войти в дом, не очистив руки огнем. Бронзовые казаны с ковшами внутри использовались не столько для гигиенических процедур, сколько в связи с ритуалами омовений. У порога ставился таз с водой и ковшом, из которого омывают руки после похорон и разводят костер в другом тазу или ведре, над которым очищают руки огнем после омовения [Ользеева, 2012, с. 245-246, 261-262].

Не может быть случайным столь детальное совпадение не встречавшихся в Восточной Европе в домонгольское время обрядовых признаков и их сочетаний, таких как: вымощенные каменные площадки; сочетание каменных и деревянных конструкций с земляными насыпями; наличие срубов, в том числе одного в другом; камни, сваленные в основании сруба; наличие большого камня в могиле; наличие приборов для омовений, жертвенных кострищ и ям для «белого» или молочного жертвоприношения, расположенного в меридиональном направлении от могилы. Можно предположить, что многогранные и прямоугольные срубы над погребениями представляют собой вариации буддийских срубных сооружений над могилами, символизирующих субурган. Прямоугольные срубы могли иметь сверху ганджир с куполом, как на надмогильных сооружениях Мон- 
голии ${ }^{3}$. В дозолотоордынское время в степях Восточной Европы подобные сооружения не известны - они могли быть привнесены сюда лишь вместе с монголами.

Останки коней, сопровождавшие погребенных, зафиксированы в восьми могилах. Чучела из черепов и скаковых конечностей отмечены трижды. В погребении 1 кургана 1 из Никифорово и погребении 1 кургана 41 из Нововасильевки (Коминтерн) чучела располагались в могилах вместе с останками человека. В первом комплексе они ориентированы на запад, во втором - на восток. В погребении 1 кургана 7 из Ютаевки череп и скаковые конечности коня найдены в заполнении потревоженной могилы, ориентированной по линии СВ Ю3. В пяти комплексах были обнаружены останки целого коня. В погребении 1 кургана 1 из Северного II скелет, ориентированный на запад, располагался на ступеньке входной ямы общей могилы. В остальных комплексах останки коня находились в отдельных ямах. В кургане 6 Дмухайловки и в кургане 3 Миновки XVII (рис. 2,III) останки коня располагались в ямах к СВ от могил погребенных и были ориентированы, как и человек, на СВ. В кургане 11 из Волошино I погребенный и останки двух коней находились в разных ямах и были ориентированы на С 3 . Скелет коня в отдельной яме сопровождал погребенного, ориентированного на С3, так же и в могиле 1 кургана 8 из Красного IV.

Сопровождение погребенных останками целого коня или его чучелом обычно считается проявлением тюркских обычаев. В Дешт-и-Кыпчак захоронения коня в могиле с человеком были широко распространены уже в раннем средневековье, но они также известны и в Центральной Азии, в том числе и в Монголии [Именохоев, 1992, с. 34-48]. В то же время целые остовы коня в отдельных ямах совершенно не типичны для половецкого погребального обряда. Их появление в Дешт-иКыпчак, по-видимому, является результатом монгольского завоевания.

В золотоордынское время в Волго-Донском регионе захоронения с конем чаще всего ориентированы в западный сектор (91 \%) [Мыськов, 2015, с. 46-49]. Среди комплексов с конем и железными конусами ориентировку на запад имеют лишь три погребения из восьми, одно направлено на северо-запад, а остальные - на север и северо-восток. Подобное сочетание тюркских и монгольских признаков в погребальном обряде может являться либо смешением разнокультурных традиций, либо сохранением общего наследия более раннего времени.

В могиле воина на южном склоне горы Булган Ундэр Улаан (Монголия) найден «полный скелет лошади, на голову, позвоночник и живот которой была надета подпруга с железными пластинами. На ребрах лошади с правой стороны лежала берцовая кость барана - «хонт». В другом могильнике была обнаружена могила уйгурского периода, в которой берцовая кость барана находилась на животе лошади» [Улийбаяр и др., 2010, с. 233]. В могильнике Тавантолгой XIII-XIV вв., в котором ярко выражены проявления буддизма, также есть погребения с северной ориентировкой и конем, причем погребение 10 выделялось особо - как захоронение «необычного человека». Останки скелета взрослого мужчины были разрушены и сдвинуты с места, череп располагался на крышке гроба. Остов коня отделен от человека вертикально поставленной каменной плитой, скелет также разрушен, а череп ориентирован на север. На нем была узда с украшениями и удилами, рядом находилось седло с изображением дракона и цветов. В инвентаре комплекса представлены серьги из яшмы и лазурита, скрепленные золотой нитью. В других погребениях Тавантолгоя встречены целые конские остовы, отдельный череп, уложенный на колчан, а также «чучело» с вертикально установленными скаковыми конечностями, поверх которых находилось седло, а на нем - череп коня. В Тавантолгое также имеются погребения с такими буддийскими атрибутами, как ваджра и жемчужина в золотой оправе, зажатая в кулаке. Кроме захоронений с северной ориентировкой в могильнике есть и погребения, обращенные на запад [Улийбаяр и др., 2010, с. 233].

Конские черепа без нижних челюстей, обнаруженные на уровне древней погребенной почвы в Нагавском I, курган 1, погребение 1, и в ровике из Аксая III, курган 2, погребение 1, не являются сопроводительными, а отражают существование какого-то иного цикла постпогребальных поминальных действий вокруг данных могил. 
Кости животных в могилах отмечены в материалах 38 погребений с железными конусами. В 34 случаях это были кости овцы (барана), в том числе: отдельные конечности -28 , лопатка с конечностями или без них 11 , альчики или астрагалы вместе с другими костями -4 , скелет без черепа - 1 экз. В 14 могилах трубчатые фаланги овцы располагались в изголовье или у плеч погребенных. В погребении 1 кургана 2 из Карасуыра (рис. 3,I) и в погребении 1 кургана 10 из Волошино I они были зафиксированы вертикально вкопанными. Вертикально расположенная голень овцы определяется этнокультурным признаком погребений монголов на самых разных территориях [Акматов, Табалдиев, 2017; Улийбаяр и др., 2010, с. 211-234].

Вопросы семантики использования в золотоордынских погребениях костей конечностей и лопаток овцы с учетом этнографических материалов монгольских народов подробно рассматривались В.А. Ларенок. Они использовались в обряде так называемого последнего кормления старца, когда куски курдючного сала, положенные на баранью лопатку, закладывали старику в рот с помощью берцовой кости. В результате человек умирал, а кости оставляли в его могиле [Ларенок, 1992, с. 181, 183].

Обряд «почетной смерти» для стариков обычно связывают с тем, что берцовая кость для монголов «воплощала собой жизненный потенциал (сульдэ) и являлась средством его передачи от умирающего старика к юноше, вступающему в жизнь». Кроме того, берцовая кость барана связывалась и с представлением об отцовском начале, а лопатка - с материнским. Использование этих костей в свадебных обрядах и ритуалах отражает идеи возрождения и перерождения. Ритуальные действия с берцовой костью и лопаткой считаются этнографической спецификой монгольских народов, что, возможно, было связано с распространением у них буддизма [Бадмаев, 2015, с. 257]. Подтверждением существования буддийской идеи перерождения, возможно, является уникальный случай, зафиксированный в погребении 4 кургана 11 из Волошино I. Здесь у черепа скелета мужчины 4045 лет находились два астрагала и вертикально поставленная локтевая кость ребенка, взя- тая из прорезанного этой могилой захоронения эпохи бронзы. В аналогичном погребении 1 кургана 10 из Волошино I в изголовье скелета мужчины 20-25 лет была зафиксирована ямка с вертикально поставленной в нее костью конечности барана и лопаткой. В комплексе также имелись два астрагала с насечками и следами красной краски, а также скорлупа куриных яиц. В обоих могилах было зафиксировано наличие железных конусов, в один из которых был вложен железный шарик, а в другой - шарик из ткани [Супруненко и др., 2006]. Очевидно, что вертикально стоявшая кость руки ребенка заменяла конечность барана и могла символизировать идею перехода сульдэ от умершего мужчины к ребенку. Открытым остается вопрос о том, почему на территории Монголии берцовая кость овцы обычно устанавливалась в вертикальном положении, что являлось естественным символом мужского начала, а в Тянь-Шане, Забайкалье и в Дешт-и-Кыпчак она чаще укладывалась горизонтально [Табалдиев, 2013; Акматов, Табалдиев, 2017, с. 73] ${ }^{4}$.

Данные об ориентировках погребенных в могилах с железными конусами имеются по 65 комплексам, остальные разрушены, либо эти сведения отсутствовали. Ориентировку на север имеют 11 погребений; на север - северо-восток - 11 ; на северо-восток 27 ; на северо-запад - 4; на восток - 3; на запад -8 ; на юго-запад -1 . Таким образом, в захоронениях с железными конусами абсолютное большинство погребенных имели ориентировки в северный сектор - 75,38 \%; запад $12,31 \%$; северо-запад - $6,15 \%$; восток $4,62 \%$; юг $-1,54 \%$. В то же время сравнение ориентировок в северный и западный сектора с общим количеством исследованных кочевнических погребений Волго-Донских степей показывает противоположное соотношение: северные направления - около $20 \%$, западные - около $70 \%$; все остальные - $10 \%$. В Западном Казахстане: северные - 22,2 \%, западные - 73,6 \% [Мыськов, 2015, с. 44]. Абсолютное преобладание северных ориентировок в погребениях с железными конусами в совокупности с остальными особенностями свидетельствует об устойчивости и определенной этнической самобытности данной группы населения Улуса Джучи. 
Связь ориентировок погребенных с теми или иными этнокультурными группами средневекового населения является одним из наиболее дискуссионных вопросов. В.В. Бартольд считал, что у степных народов, как тюркских, так и монгольских, священной стороной изначально являлся восток, соответствовавший ориентации погребенных на запад. У китайцев священной стороной был юг, соответственно мир мертвых располагался у них на севере. По мнению В.В. Бартольда, в $\mathrm{X}-\mathrm{XII}$ вв., в связи с распространением в Монголии буддизма, культ юга вытеснял более ранний традиционный культ востока, «а при Чингисхане он сделался официальным уже для всей степи, подчинявшейся монголам». У кочевников, воспринявших буддизм из Китая, почитание юга проявляется до настоящего времени в расположении кибиток выходом к югу, независимо от того, тюрки они или монголы. Но у тех, кто буддизм не принял, оставшись шаманистами, продолжал сохраняться культ востока. «Память о шаманских обычаях, в особенности обрядах погребения, быстро исчезла в Монголии под влиянием буддизма» [Бартольд, 1966, с. 393-394]. Речь, таким образом, должна идти не о проявлении традиционных тюркской или монгольской этнических традиций погребальной ориентации, а о соотношении буддийской и языческой традиций. Если северная ориентировка заимствована монголами из Китая и была, как считал В.В. Бартольд, связана с распространением буддизма, то западная ориентировка сохраняется у них как более древняя тюрко-монгольская традиция. В связи с этим при сопоставлении погребальных обрядов двух основных групп кочевого населения Золотой Орды монгольской и тюркской (кыпчакской) - северная ориентировка должна иметь преимущественно монгольскую основу, а западная тюркскую [Мыськов, 2015 с. 272-279, 281]. Это связано не только с этнокультурными традициями, но и со всей системой мировоззрения, государственной и социальной организацией общества, которые у монголов определяются по меридиональным, а у тюрок - по широтным направлениям. Деление войска, государственных структур, территории и всего иного пространства на переднюю и заднюю части, левое и правое крыло у монголов определяет- ся как юг - перед, север - левое, восток правое крыло; а у тюрков, соответственно, восток - перед, запад - зад; юг - левое, север правое крыло [Семби, 2013, с. 15-20, 89-99].

Другой важный вопрос связан с поиском причин отклонения ориентировок погребенных от севера в направлении к северо-востоку. М.M. Содномпилова обратила внимание на существующее в некоторых этнических сообществах монгольского мира несовпадение основных ориентационных направлений с базовыми направлениями общепринятой классической пространственной схемы. Последние зачастую заменяются промежуточными направлениями. В языках монголоязычных и у некоторых тюркских народов даже нет слов для обозначения промежуточных направлений, так как «вместо понятий о сторонах света выступают понятия об углах света» [Содномпилова, 2009, с. 42-46]. Северная сторона, или северный угол, в мифопоэтическом понимании по направлению к восходу солнца одновременно может быть как севером, так и северо-востоком, что вполне согласуется также и с идеей перерождения. «Подтверждением актуальности образа северной стороны как обители мертвых служит ориентация умершего головой в северном направлении (север, северо-запад, северо-восток) в традиции большинства этнических групп бурят и монголов. У захчинов лицо умершего обращали на северо-запад, голову на северо-восток, что указывает на то, что у захчинов плохой стороной или направлением считался северо-восток» [Содномпилова, 2009, с. 145]. Значение северной и северо-восточной сторон в погребальном обряде монголов равнозначно, и меридиональная концепция мироздания при этом полностью сохраняется: юг - передняя, «правильная» сторона (направление) - мир живых; север - задняя, обратная, «неправильная» сторона (направление) - мир мертвых. В этой связи представляется, что абсолютное преобладание северных направлений (включая северо-восточные) в погребениях с конусами определенно свидетельствует о том, что этническую основу этой группы кочевников составляли носители монгольской культурной традиции. Ориентировки между севером и северо-востоком являются для них нормой, а остальные выступают отклонением от нормы 
или смешением монгольской с тюркской или иными культурными традициями.

Краниологические определения, представленные антропологами, имеются по пяти комплексам (табл. 2). В дополнение к ним могут быть привлечены данные еще о пяти погребениях, расположенных в тех же могильниках, но не имеющих в составе инвентаря конусов. Девять из десяти захоронений имели ориентировку на север - северо-восток и ярко выраженныепризнаки монголоидности центральноазиатского типа. Лишь погребенный из Волошино I, курган 11, погребение 4, с северо-западной ориентировкой имел смешанные признаки европеоида и монголоида североазиатского или центральноазиатского типа и являлся метисом. Антропологические определения погребенных с конусами, таким образом, в целом также находятся в рамках общей тенденции принадлежности памятников к представителям центральноазиатских монгольских этнических групп.

Определение ДНК погребенного из Карасуыр, курган 1, погребение 1, ориентированного на север, также укладывается в общую тенденцию. Выявленные Y-хромосомы этого комплекса относятся к гаплогруппе C-Y4580, или C-F9700. Данный тип называют Starcluster, или «гаплотип Чингисхана», и определяют одним из важнейших субкладов культуры этнических монголов [Усманова и др., 2020, с. 203-204].

Нарушение сохранности останков погребенных отмечено в 25 комплексах из 69, имеющих соответствующие данные (36 \%). Все кости погребенных из курганов 3 и 4 могильника Аглос (Рассвет III) были перемешаны и сдвинуты в одну сторону, но в ямах вместе с обильным инвентарем сохранилось, соответственно, шесть и четыре серебряных дирхемов. В погребении 1 кургана 2 из Весёлого II кости скелета также были сдвинуты, но инвентарь сохранился практически в целостности. В погребении 1 кургана 1 из Горно-Пролейского II форма могилы соответствует ограблению, но следов затека и наличия костей скелета зафиксировано не было, а найденные вещи находились в восточной части ямы на дне. Данная ситуация больше похожа на кенотаф или преднамеренное изъятие трупа из могилы. В Русском Колодце VII, курган 5, погребение 1, могила после разрушения была засыпана камня- ми. В погребении 1 кургана 25 Семёнкина, погребении 1 Маляевки и погребении 1 кургана 5 Сенного (рис. 3,III) скелеты погребенных разрушены лишь в районах грудной клетки и черепа, но сопровождавшиеся вещи почти не потревожены. Аналогичная ситуация фиксируется и в Монголии. В могильнике Тавантолгой часть погребений была разрушена, но знаковые и ценные вещи в них сохранялись. Предположение о том, что такие могилы грабили «мародеры, нищие монголы» [Улийбаяр и др., 2010, с. 229-230], вызывает сомнение.

В нескольких погребениях с железными конусами зафиксированы признаки постпогребальных действий с останками. В погребении 2 кургана 8 Бударки 3 череп был сдвинут, а между ним и костями туловища помещена тушка барана без головы (рис. 4,I). В погребении 1 кургана 11 из Высочино II предплечье и кисть правой руки погребенного мужчины были отделены и помещены кистью вниз в бронзовый котел, стоявший в ногах (рис. 4,II). Следы отчленения на костях при этом не фиксировались. Следовательно, такие действия могли совершаться лишь после частичного разложения мягких тканей. В погребении 1 кургана 5 Кривой Луки XVI скелет погребенного был частично разрушен в области груди (рис. 2,I). В этом комплексе, как и в вышеупомянутых, сохранился разнообразный инвентарь, в том числе серебряные монеты. Полевые наблюдения позволили Г.А. Фёдорову-Давыдову сделать вывод о том, что насыпь этого кургана была сооружена не сразу, а лишь спустя некоторое время после обряда погребения. Разрушение скелета произошло уже после распада сухожилий в промежутке времени «между смертью и первичным погребением и окончательным погребением», когда был насыпан курган [Фёдоров-Давыдов, 1984, с. 105-106].

Сам по себе обряд обезвреживания покойника имеет широкое временное и территориальное распространение. Он, в частности, широко представлен в погребениях огузов X начала XI в. [Круглов, 2003], как известно ушедших на запад в VIII в. именно из Монголии, и вполне может иметь общие тюрко-монгольские корни. В контексте монгольской этнокультурной традиции те или иные ритуальные разрушения и постпогребальные действия 
с останками и костями могут являться как реминисценцией древних шаманских культов, так и отражением новых буддийских обрядов, для которых также были характерны различные манипуляции с костями скелета уже после разложения трупа.

Таким образом, анализ особенностей погребального обряда показывает, что захоронения с железными конусами характеризуются необычайно высокой концентрацией достаточно специфических признаков, что позволяет сделать вывод о принадлежности данных памятников к вполне определённой этнокультурной группе средневекового населения.

Особенности топографического размещения погребений на северных и южных склонах возвышенностей, водоразделов, во впадинах и лощинах имеют устойчивые соответствия в топографии погребальных памятников монгольских народов.

Сооружение бревенчатых конструкций над неординарными погребениями совпадает с традицией сооружения срубов над могилами нойонов Монголии. Использование камня в могилах и над могилами имеет богатые аналогии в Центральной Азии. Наличие костей овцы, включая конечности, вертикально поставленные в изголовье погребенных, является особой этнокультурной спецификой монгольских захоронений. Наличие сопровождающих захоронений коня как в отдельных могилах, так и в одной общей могиле не является исключительной прерогативой тюркского погребального обряда. Они фиксируются, в частности, также и в тавантолгойской культуре на р. Онон в северо-восточной Монголии. Преобладание практики ориентации умерших в направлении на север и северо-восток является еще одним составляющим признаком монгольской погребальной обрядности. Данные краниологии также свидетельствуют о центральноазиатском монгольском происхождении.

На основе всего вышеуказанного предлагается вывод, что кочевнические захоронения с железными конусами на территории Улуса Джучи являются монокультурными. По специфическим (топография могил, сооружение срубов, использование камня, огненные ритуалы) и доминантным признакам погребальной обрядности (использование трубчатой кости овцы / барана, в том числе установленной вер- тикально; ориентация покойных на север - северо-восток) можно заключить, что данные памятники оставлены носителями монгольских этнокультурных традиций с проявлением шаманских и буддийских ритуалов. Судя по датам монет (табл. 1), основные монгольские этнические традиции устойчиво сохранялись данным населением до самого конца XIV века.

\section{ПРИМЕЧАНИЯ}

${ }^{1}$ Работа выполнена при поддержке гранта РФФИ № 19-09-00471 «Палеоантропология древнего и средневекового населения Нижнего Поволжья (палеопатологический аспект)».

The research was supported by RFBR grant "Paleoanthropology of the ancient and medieval population of the Lower Volga River region (paleopathological aspect)", № 19-09-00471.

${ }^{2}$ Авторы признательны В.А. Бабенко, А.В. Евглевскому, М.В. Квитницкому, В.Ю. Макласову, А.Н. Масловскому, Е.И. Нарожному, М.А. Очир-Горяевой, К.А. Руденко, Д.С. Соловьёву - друзьям и коллегам за помощь, оказанную в сборе первичной научной информации о погребениях Улуса Джучи с конусами.

${ }^{3}$ Сооружение срубов вокруг и над могилами высшей провинциальной знати Монголии, исповедовавшей буддизм, возможно является реминисценцией шаманских культов лесных народов Южной Сибири и Центральной Азии. Н.Л. Жуковская высказала такое предположение, сравнивая срубы монгольских нойонов с примитивными шаманскими деревянными «домами духов». Также она провела параллели между срубами и обрядами захоронения лам в более скромных деревянных гробницах бурят и тувинцев. Она отметила, что кроме наличия «ганджира и позы махапаринирваны» (на правом боку, голова на север, лицо на запад, правая рука у щеки) у единственного сохранившегося покойника, никаких других проявлений буддизма не было [Жуковская, 1989]. Остатки бревенчатых конструкций в золотоордынских курганах имеют более внушительные размеры, чем сооружения, окружавшие могилы нойонов. Это позволяет в большей степени сопоставлять их с погребениями знати, чем с шаманскими домами духов.

${ }^{4}$ Ритуал «почетной смерти» мужчин старческого возраста невозможно напрямую связывать с находками в погребениях берцовых костей овцы, так как они встречаются в могилах с останками погребенных разного возраста, в том числе и женских. Вероятно, кости овцы являлись символами как мужского начала, так и буддийской идеи перерождения. 


\section{ПРИЛОЖЕНИЯ}

\section{Таблица 1. Наличие монет в погребениях с железными конусами}

\section{Table 1. Presence of coins in burials with iron cones}

\begin{tabular}{|c|c|}
\hline Комплекс & Количество монет и их определения \\
\hline $\begin{array}{l}\text { Комсомольский, } \\
\text { мавз. 2, погр. } 2\end{array}$ & 1 динар: ал-Мелик аз-Закыр Рукн-ад-Дин Бейбарс, Каир, 1260-1277 \\
\hline $\begin{array}{c}\text { Ютаевка, } \\
\text { кург. 7, погр. } 1\end{array}$ & 1 дирхем: Токта, Сарай ал-Махруса, 1311 \\
\hline $\begin{array}{l}\text { Красный IV, } \\
\text { кург. 8, погр. } 1\end{array}$ & 5 дирхемов: Узбек, 1316/17 \\
\hline $\begin{array}{c}\text { Аглос (Рассвет III), } \\
\text { кург. 3, погр. } 1 \\
\end{array}$ & 6 дирхемов: 2 - Узбек, Азак, 1315/20, остальные не определены \\
\hline $\begin{array}{c}\text { Аглос (Рассвет III), } \\
\text { кург. 4, погр. } 1\end{array}$ & 4 дирхема: Узбек, Азак, 1315/20 \\
\hline $\begin{array}{c}\text { Сенной, } \\
\text { кург. 5, погр. } 1\end{array}$ & $\begin{array}{c}8 \text { дирхемов: } 1 \text { - Токта, Сарай ал-Махруса, 1310/11; } 1 \text { - Узбек, } \\
\text { Сарай ал-Махруса, 1322; } 6 \text { - Джанибек, Сарай ал-Джедид, 1342-1346 }\end{array}$ \\
\hline $\begin{array}{c}\text { Кривая Лука XVI, } \\
\text { кург. 5, погр. } 1\end{array}$ & $\begin{array}{c}11 \text { дирхемов: } 1 \text { - Узбек, Сарай ал-Махруса, 1322; } \\
1 \text { - Узбек, Сарай, год не определен; } 1 \text { - Джанибек, Хорезм, 1344/45; } \\
1 \text { - Бирдибек, Гюлистан, 1358/59; } 7 \text { - не определены }\end{array}$ \\
\hline $\begin{array}{l}\text { Миновка XVII, } \\
\text { кург. 3, погр. } 2\end{array}$ & $\begin{array}{c}5 \text { дирхемов: } 2-\text { Узбек, 1313/39; } 2 \text { - Навруз, Азак, 1359; } \\
1 \text { - Навруз, Гюлистан, } 1360\end{array}$ \\
\hline $\begin{array}{c}\text { Саратов, } \\
\text { Вишнёвая гора }\end{array}$ & $\begin{array}{c}11 \text { дирхемов, все Азак: } 4 \text { - Бирдибек, 1357/58; } 1 \text { - Хызр, 1360/61; } \\
6 \text { - Абдуллах, 1363/64 }\end{array}$ \\
\hline $\begin{array}{l}\text { Дмухайловка, } \\
\text { кург. } 6, \text { погр. } 1\end{array}$ & 3 дирхема: 1 - Абдуллах, Орда, 1368/69; 2 - Мухаммед-Булак, Орда, 1370-1380 \\
\hline
\end{tabular}

Таблица 2. Краниологические определения погребенных из могил с конусами, выполненные А.В. Шевченко, М.А. Балабановой, И.П. Панюшкиной и С.О. Горбенко (по: [Мыськов, 2015, с. 287, 344; Усманова и др., 2020, с. 203; Супруненко и др., 2006, с. 113-135])

Table 2. Craniological definitions of individuals berried in the cones graves was conducted by anthropologists A.V. Shevchenko, M.A. Balabanova, I.P. Panyushkina, S.O. Gorbenko (after: [Myskov, 2015, p. 287, 344; Usmanova et al., 2020, p. 203; Suprunenko et al., 2006, p. 113-135])

\begin{tabular}{|c|c|c|c|c|c|}
\hline Комплекс & $\begin{array}{l}\text { Наличие } \\
\text { конусов }\end{array}$ & Пол & Возраст & Антропологические признаки & $\begin{array}{l}\text { Ориен- } \\
\text { тировка }\end{array}$ \\
\hline $\begin{array}{l}\text { Нагавский I, } \\
\text { кург. } 1 \text {, погр. } 1\end{array}$ & 3 жел. & Ж & $45-50$ & $\begin{array}{c}\text { Выраженная монголоидность } \\
\text { центрально-азиатского (ц/а) типа }\end{array}$ & $\mathrm{CB}$ \\
\hline $\begin{array}{l}\text { Нагавский I, } \\
\text { кург. 2, погр. } 1\end{array}$ & 1 жел. & $\mathrm{M}$ & $20-25$ & Выраженная монголоидность ц/а типа & CB \\
\hline $\begin{array}{l}\text { Нагавский IV, } \\
\text { кург. } 1, \text { погр. } 1\end{array}$ & 1 бронз. & & $20-25$ & Монголоидность & \\
\hline $\begin{array}{c}\text { Тормосин, } \\
\text { кург. } 1, \text { погр. } 1\end{array}$ & 1 жел. & $\mathrm{M}$ & $?$ & Выраженная монголоидность ц/а типа & $\mathrm{CB}$ \\
\hline $\begin{array}{c}\text { Карасуыр, } \\
\text { кург. 2, погр. } 1\end{array}$ & 1 жел. & $\mathrm{M}$ & $25-30$ & Выраженная монголоидность ц/а типа & $\mathrm{C}$ \\
\hline $\begin{array}{c}\text { Волошино I, } \\
\text { кург. } 11, \text { погр. } 4\end{array}$ & 1 жел. & M & $\begin{array}{l}44-50 \\
60-70\end{array}$ & $\begin{array}{c}\text { Монголоидность северо- или ц/а типа } \\
\text { и европеоидность (метис?) }\end{array}$ & C3 \\
\hline
\end{tabular}


I.I. Dremov, E.V. Kruglov. Iron Cones in the Burials of Ulus Jochi: Aspects of Ethnocultural Identification

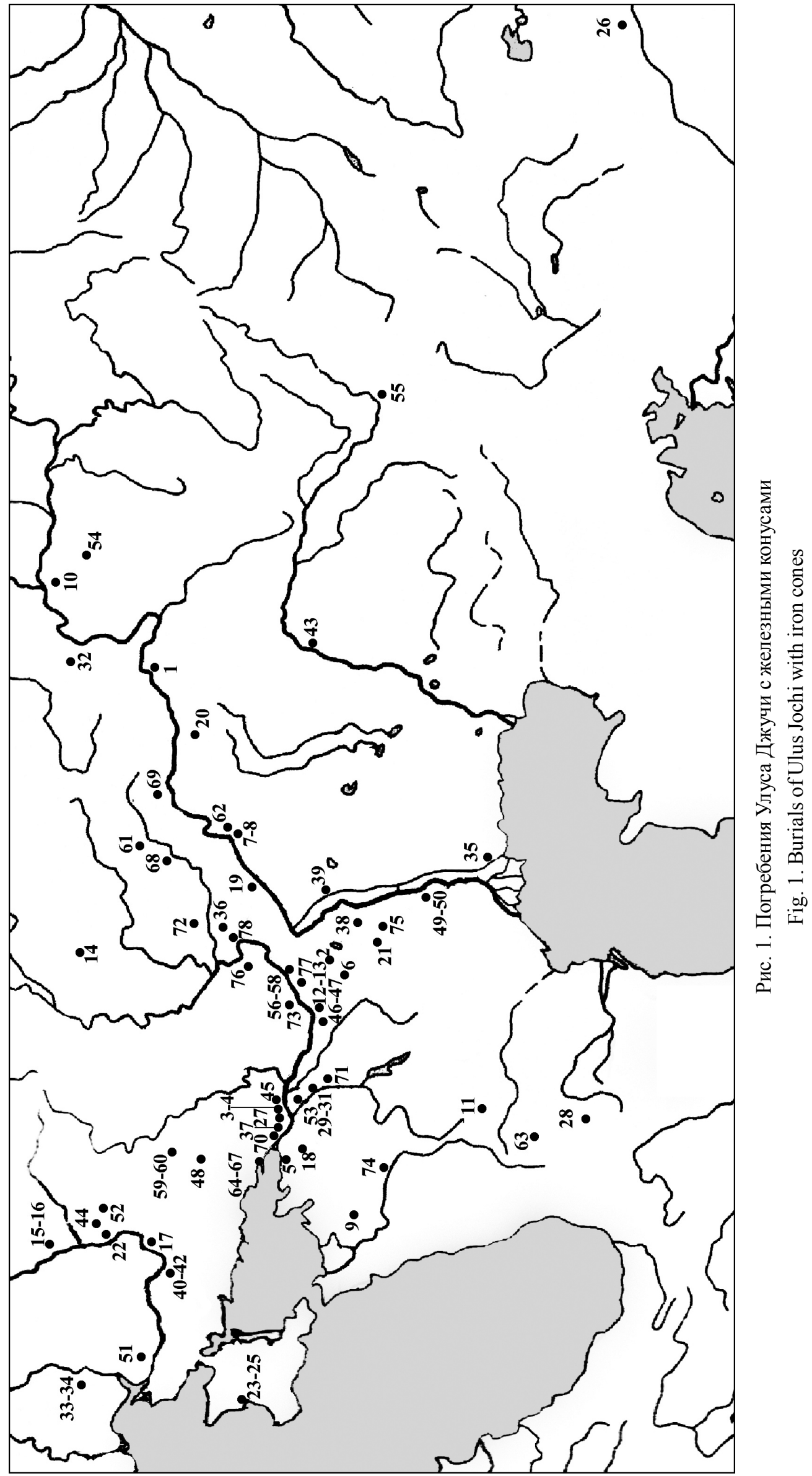


Рис. 1. Погребения Улуса Джучи с железными конусами:

1 - Абашево, кург. 1, погр. 1; 2 - Абганерово IV, кург. 10, погр. 1; 3, 4 - Аглос (Рассвет III), кург. 3, погр. 1; кург. 4, погр. 1; 5 - Азов, ул. Красноармейская, 56, погр. 9; 6 - Аксай III, кург. 2 погр. 1; 7, 8 - Бережновка I, кург. 47,

погр. 1; кург. 50, погр. 1; 9 - Бойко-Понура I, кург. 1, погр. 2; 10 - Болгар, Восточный въезд, погр. 4; 11 - Бударка 3 , кург. 8, погр. 2; 12 - Весёлый II, кург. 2, погр. 1; 13 - Весёлый V, кург. 1, погр. 1; 14 - Власовский I, кург. 15, погр. 3; 15, 16 - Волошино I, кург. 10, погр. 1; кург. 11, погр. 4; 17 - Вороная (Рясные могилы), кург. 7, погр. 1; 18 - Высочино II, кург. 11, погр. 1; 19 - Горно-Пролейский II, кург. 1, погр. 1; 20 - Давыдовка III, кург. 11, погр. 1; 21 - Джангар II-88, кург. 2, погр. 1; 22 - Дмухайловка, кург. 6, погр. 1; 23, 24, 25 - Евпатория (оз. Сасык), погр. 1, 7, 10; 26 - Карасуыр, кург. 2, погр. 1; 27 - Каршинский, кург. 16, погр. 1; 28 - Келийский могильник, погр. 247; 29 - Кировский IV, кург. 10, погр. 1; 30, 31 - Кировский V, кург. 4, погр. 1; кург. 7, погр. 1; 32 - Клин I, кург. 1, погр. 2; 33, 34 - Ковалевка IV, кург. 4, погр. 1; кург. 10, погр. 1; 35 - Комсомольский, мавз. 2, погр. 2; 36 - Красная Котлубань, кург. 1, погр. 1; 37 - Красный IV, кург. 8, погр. 1; 38 - Кривая Лука XVI, кург. 5, погр. 1; 39 - Маляевка, погр. 1; 40 - Мамай-Гора, Восточная группа, погр. 3; 41, 42 - Мамай-Гора, объект 184, погр. 6, кург. 191, погр. 2; 43 - Мамбетбай, кург. 3, погр. 1; 44 - Миновка XVII, кург. 3, погр. 2; 45 - Мухин I, кург. 6, погр. 1; 46, 47 Нагавский I, кург. 1, погр. 1, кург. 2, погр. 1; 48 - Никифорово, кург. 1, погр. 1; 49, 50 - Никольское I, кург. 3 , погр. 1; кург. 8, погр. 1; 51 - Нововасильевка (Коминтерн), кург. 41, погр. 1; 52 - Ново-Подкряж, кург. 6, погр. 1; 53 - Новосадковский, кург. 19, погр. 1; 54 - Ново-Серёжино, могильник; 55 - Новый Кумак II, кург. 3, погр. 1; 56, 57, 58 - Первомайский VII, кург. 45, погр. 1; кург. 52, погр. 1; кург. 57, погр. 1; 59, 60 - Пески, кург 17, погр. 1; кург. 22, погр. 1; 61 - Песковка, кург. 1, погр. 1; 62 - Потёмкино, кург. 7, погр. 1; 63 - Пятигорск (ур. Гора), кург. 8, погр. 1; 64, 65, 66, 67 - Русский Колодец VII, кург. 5, погр. 1; кург. 7, погр. 2; кург. 10, погр. 1; кург. 11, погр. 1; 68 - Рыбинка, кург. 1, погр. 1; 69 - Саратов, Вишнёвая гора, погр.; 70 - Северный II, кург. 1, погр. 1; 71 - Семёнкин, кург. 25, погр. 1; 72 - Сенной, кург. 5, погр. 1; 73 - Тормосин, кург. 1, погр. 1; 74 - Усть-Лабинск, кург. 8, погр. 1; 75 - Хар Нуурин Толга, кург. 9, погр. 1; 76 - Хмелевой I, кург. 7, погр. 1; 77 - Шебалино, кург. 2, погр. 1; 78 - Ютаевка, кург. 7, погр. 1

Fig. 1. Burials of Ulus Jochi with iron cones:

1 - Abashevo, kurgan 1, burial 1; 2 - Abganerovo IV, kurgan 10, burial 1; 3, 4-Aglos (Rassvet III), kurgan 3, burial 1; kurgan 4, burial 1; 5 - Azov, ul. Krasnoarmeyskaya, 56, burial 9; 6 - Aksay III, kurgan 2, burial 1; 7,8-Berezhnovka I, kurgan 47, burial 1; kurgan 50, burial 1; 9 - Boyko-Ponura I, kurgan 1, burial 2; 10 - Bolgar, Vostochnyy v'ezd, burial 4; 11 - Budarka 3 , kurgan 8 , burial 2; 12 - Vesyolyy II, kurgan 2, burial 1; 13 - Vesyolyy V, kurgan 1, burial 1; 14 - Vlasovskiy I, kurgan 15, burial 3; 15, 16 - Voloshino I, kurgan 10, burial 1; kurgan 11, burial 4; 17 - Voronaya (Ryasnye mogily), kurgan 7, burial 1; 18 - Vysochino II, kurgan 11, burial 1; 19 - Gorno-Proleyskiy II, kurgan 1, burial 1; 20 - Davydovka III, kurgan 11, burial 1; 21 - Dzhangar II-88, kurgan 2, burial 1; 22 - Dmuhaylovka, kurgan 6, burial 1; 23, 24, 25 - Evpatoriya (oz. Sasyk), burial 1, 7, 10; 26 - Karasuyr, kurgan 2, burial 1; 27 - Karshinskiy, kurgan 16, burial 1; 28 - Keliyskiy m-k, burial 247; 29 - Kirovskiy IV, kurgan 10, burial 1; 30, 31 - Kirovskiy V, kurgan 4, burial 1; kurgan 7, burial 1; 32 - Klin I, kurgan 1, burial 2;

33, 34 - Kovalevka IV, kurgan 4, burial 1; kurgan 10, burial 1; 35 - Komsomol'skiy, mavz. 2, burial 2; 36 - Krasnaya

Kotluban', kurgan 1, burial 1; 37 - Krasnyy IV, kurgan 8, burial 1; 38 - Krivaya Luka XVI, kurgan 5, burial 1; 39 - Malyaevka, burial 1; 40 - Mamay-Gora, Vostochnaya gruppa, burial 3; 41, 42 - Mamay-Gora, ob'ekt 184, burial 6; kurgan 191, burial 2; 43 - Mambetbay, kurgan 3, burial 1; 44 - Minovka XVII, kurgan 3, burial 2; 45 - Muhin I, kurgan 6, burial 1; 46, 47 - Nagavskiy I, kurgan 1, burial 1; kurgan 2, burial 1; 48 - Nikiforovo, kurgan 1, burial 1; 49, 50 - Nikol'skoe I, kurgan 3, burial 1; kurgan 8, burial 1; 51 - Novovasil'evka (Komintern), kurgan 41, burial 1; 52 - Novo-Podkryazh, kurgan 6, burial 1; 53 - Novosadkovskiy, kurgan 19, burial 1; 54 - Novo-Seryozhino, m-k; 55 - Novyy Kumak II, kurgan 3, burial 1; 56, 57, 58 - Pervomayskiy VII, kurgan 45, burial 1; kurgan 52, burial 1; kurgan 57, burial 1;

59, 60 - Peski, kurgan 17, burial 1; kurgan 22, burial 1; 61 - Peskovka, kurgan 1, burial 1; 62 - Potyomkino, kurgan 7, burial 1; 63 - Pyatigorsk (ur. Gora), kurgan 8, burial 1; 64, 65, 66, 67 - Russkiy Kolodec VII, kurgan 5, burial 1; kurgan 7, burial 2; kurgan 10, burial 1; kurgan 11, burial 1; 68 - Rybinka, kurgan 1, burial 1; 69 - Saratov, Vishnyovaya gora, burial; 70 - Severnyy II, kurgan 1, burial 1; 71 - Semyonkin, kurgan 25, burial 1; 72 - Sennoy, kurgan 5, burial 1; 73 - Tormosin, kurgan 1, burial 1; 74 - Ust'-Labinsk, kurgan 8, burial 1; 75 - Har Nuurin Tolga, kurgan 9, burial 1; 76 - Hmelevoy I, kurgan 7, burial 1; 77 - Shebalino, kurgan 2, burial 1; 78 - Yutaevka, kurgan 7, burial 1 


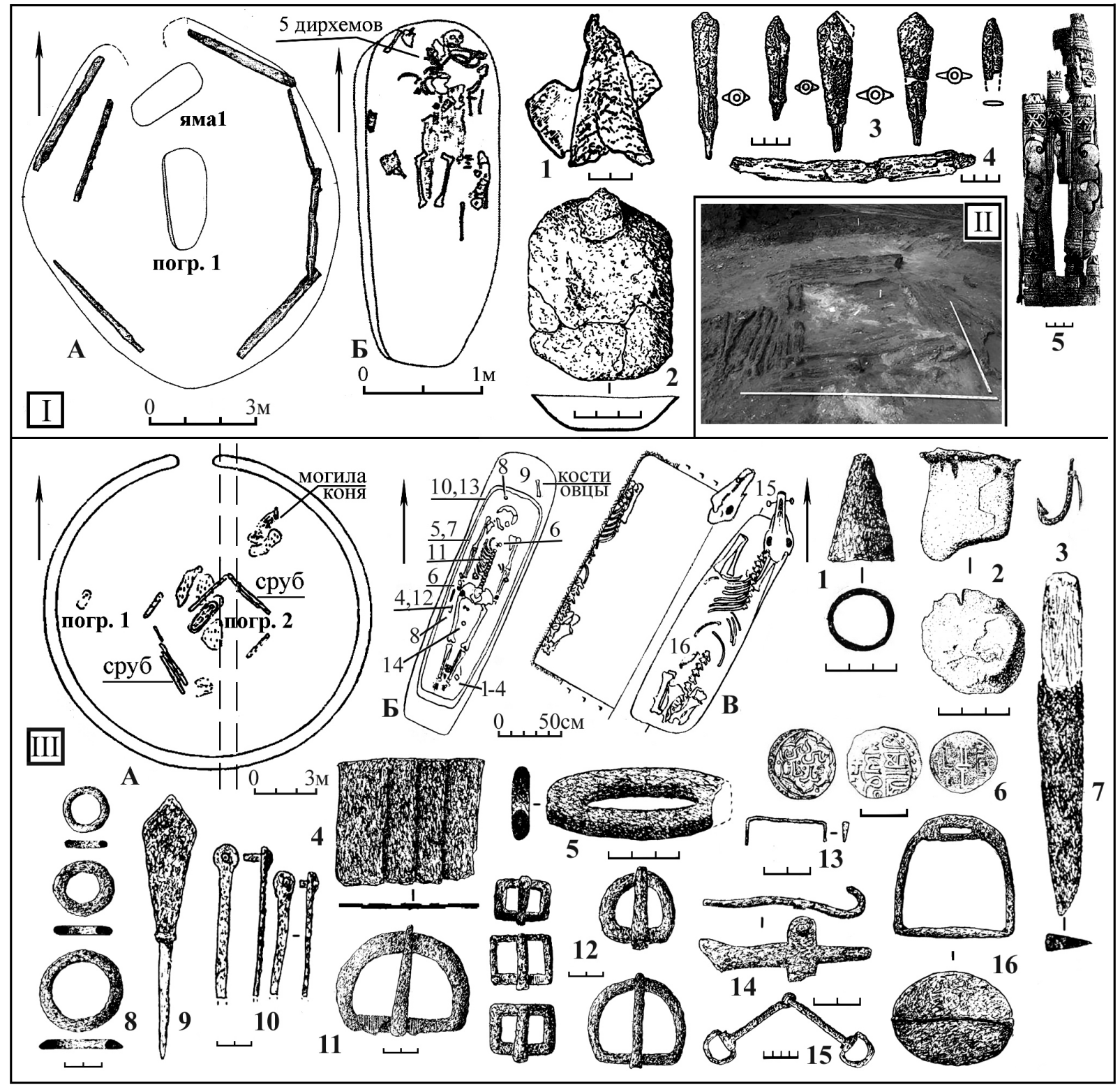

Рис. 2. Курганы со срубами.

$I$ - Кривая Лука XVI, кург. 5, погр. 1. A- план кургана, 5 - план погребения.

Могильный инвентарь: 1 - конус на железной пластине; 2 - железные плошка и пластина; 3 - наконечники стрел; 4 - нож; 5 - колчан (по: [Дворниченко и др., 1976, рис. 122; Фёдоров-Давыдов, 1984, рис. 1-4]).

II - Клин I, кург. 1, погр. 2. Фото бревенчатой конструкции под насыпью (по: [Курганный могильник Клин I]). $I I I$ - Миновка XVII, кург. 3, погр. 2. $A$ - план кургана, 5 - план погребения, $B$ - план могилы коня.

Могильный инвентарь (порядковые номера предметов могильного инвентаря здесь и на рис. 3-4 соответствуют позициям на планах погребений): 1 - конус; 2 - медный сосуд; 3 - крючок с верёвкой; 4 - железные пластины с остатками шёлковой ткани; 5 - кресало; 6 - три дирхема на крышке гроба и пять под кистью правой руки; 7 - нож; 8 - кольца; 9 - наконечник стрелы; 10,13 - крепления гроба; 11, 12 - пряжки; 14 - крюк колчана; 15,16 - удила и стремена на крышке гроба (по: [Шалобудов, Кудрявцева, 1980, рис. 3-4])

Fig. 2. Kurgans with logs.

$I$ - Krivaya Luka XVI, kurgan 5, burial 1. $A$-plan of mound, $E$ - plan of burial.

Grave goods (The sequential numbers of the grave goods drawings here and in Fig. 3-4 correspond to the positions on the burials plans): 1 - cone on the plate; 2 - iron flat with a plate; 3 - arrowheads; 4 - knife; 5 - birch quiver

(after: [Dvornichenko et al., 1976, fig. 122; Fedorov-Davydov, 1984, fig. 1-4]. II - Klin I, kurgan 1, burial 2.

Photo of the log structure in the kurgan (after: [Kurgannyy mogil'nik Klin I]). III - Minovka XVII, kurgan 3, burial 2. $A$ - plan of kurgan, $E$ - plan of burial, $B$ - plan of horse's grave. Grave goods: 1 - cone; 2 - copper jar; 3 - fishhook with rope; 4 - iron plates with the remains of silk fabric; 5 - chaired; 6 - three silver coins on the coffin lid and five coins under the hand;

7 - knife; 8 - rings; 9 - arrowheads; 10,13 - fastenings of the coffin; 11, 12 - buckles; 14 - hook quiver; 15,16 - rod and stirrup on the lid of the coffin (after: [Shalobudov, Kudryavtseva, 1980, fig. 3-4]) 


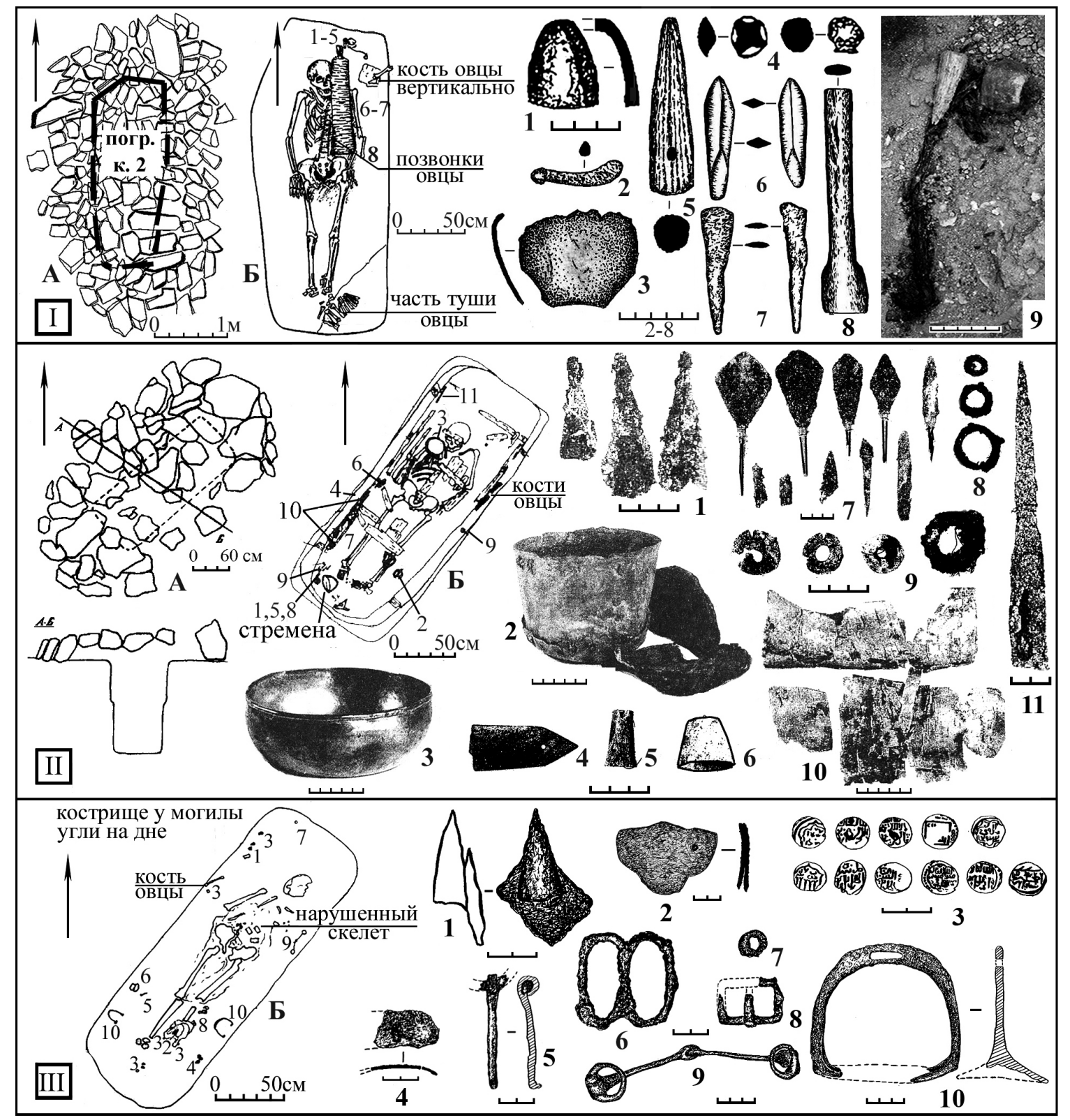

Рис. 3. Погребения с каменными насыпями и ритуальным разрушением. I- Карасуыр, курган 2, погребение 1.

$A$ - план кургана, $D$ - план погребения. Могильный инвентарь: 1 - конус; 2 - стержень; 3 - бронзовая плошка;

4 - крепежные детали; 5 - рог; 6-7 - костяные и железные наконечники стрел в колчане; 8 - срединная накладка лука;

9 - фото комплекса предметов и железного крюка (по: [Усманова и др., 2020, рис. 1,11-12,15-20, 3,6]). II - Ковалёвка, кург. 4, погр. 1 . $A$ - план кургана; $D$ - план погребения.

Могильный инвентарь: 1 - конусы; 2 - бронзовый котелок с остатками ткани; 3 - серебряная чаша; 4-5 - ворворки; 6 - оселок; 7 - наконечники стрел; 8 - железные кольца; 9 - свинцовые кольца; 10 - два берестяных колчана; 11 - наконечник копья (по: [Ковпаненко и др., 2005, рис. 31, 32, 38, 39]).

III - Сенной, кург. 5, погр.е 1. Б- план погребения. Могильный инвентарь: 1 - конус с железными пластинами;

2 - застежка сумки; 3 - дирхемы; 4 - железная пластина; 5 - стержень с фрагментом кольца; 6, 8 - пряжки; 7 - кольцо; 9 - удила; 10 - стремена (по: [Мамонтов, Ситников, 1998, рис. 1, 2])

Fig. 3. Burials with stone mounds and ritual destruction. $I$ - Karasuyr, kurgan 2, burial 1. $A$-plan of kurgan, $E$ - plan of burial. Grave goods: 1 - cone; 2 - rod; 3 - bronze flat; 4 - details of the fixtures; 5 - horn; $6-7-$ bone and iron arrowheads in a quiver; 8 - the middle overlay of the battle bow;

9 - photo of complex of objects and an iron hook (after: [Usmanova et al., 2020, fig. 1,11-12,15-20, 3,6]). $I I$ - Kovalevka, kurgan 4, burial 1. $A$ - plan of kurgan, $E$ - plan of burial. Grave goods: 1 - cones;

2 - bronze cauldron with remains of cloth; 3 - silver bowl; 4-5 - finial (vorvorka); 6 - grindstone; 7 - arrowheads; 8 - iron rings; 9 - lead plaques; 10 - two quivers; 11 - tip of the spear (peak) (after: [Kovpanenko et al., 2005, fig. 31, 32, 38, 39]). III - Sennoy, kurgan 5, burial 1. 5 - plan of burial. Grave goods: 1 - cone with iron plates; 2 - bag clasp; 3 - silver coins; 4 - iron plate; 5 - rod with a ring fragment; 6,8 - buckles; 7 - ring; 9 - rod; 10 - stirrups

(after: [Mamontov, Sitnikov, 1998, fig. 1, 2]) 


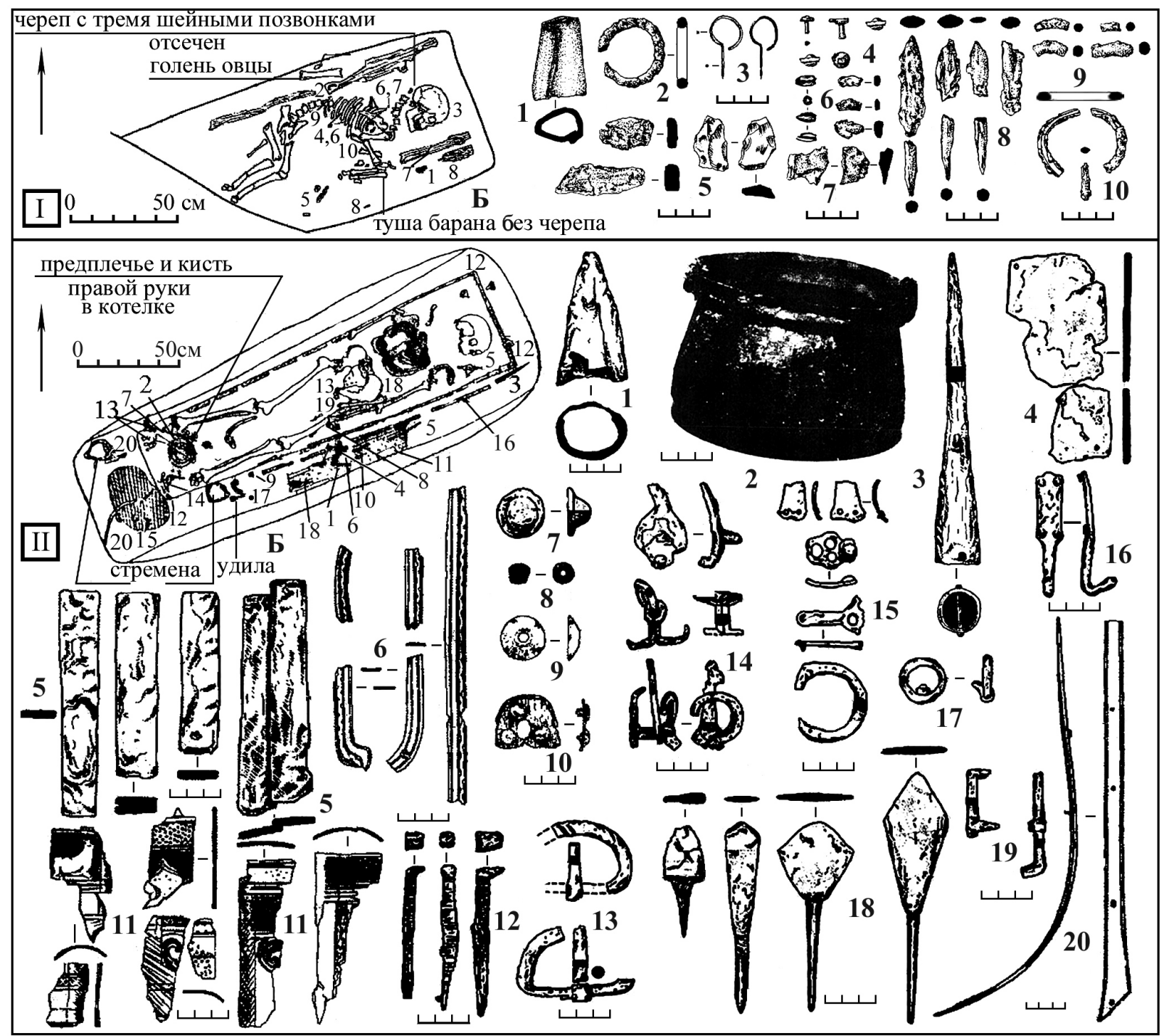

Рис. 4

Погребения с постингумационными нарушениями. $I$ - Бударка 3 , кург. 8, погр. 2 . 5 - план погребения. Могильный инвентарь: 1 - конус-втулка; 2, 9-10 - кольца; 3 - золотые серьги; 4 - заклепки; 5 - кресало с кремнем; 6 - бусины; 7 - неопределенные предметы; 8 - фрагменты наконечников стрел (по: [Савенко, 2010, рис. 3; 6]). II - Высочино II, кург. 11, погр. 1. Б- план погребения. Могильный инвентарь: 1 - конус;

2 - бронзовый котел с остатками ткани; 3 - наконечник копья (пики); 4 - железные пластины; 5 - панцирные пластины; 6, 10-11 - костяные накладки колчана; 7 - умбон щита; 8 - бусина; 9 - костяная ворворка;

12,14 - гвозди и крепления гроба; 13,17,19 - пряжки; 15 - крепления сбруи; 16 - крюк колчана;

18 - наконечники стрел; 20 - костяные накладки седла (по: [Беспалый, Лукьяшко, 2008, табл. XXVIII-XXIX])

Fig. 4

Burials with post-ingumation destructions. $I$ - Budarka 3, kurgan 8, burial 2. $E$ - plan of burial. Grave goods: 1 - cone-sleeve; 2, 9-10 - rings; 3 - gold earrings; 4 - rivets; 5 - chaired with flint; 6 - beads; 7 - plates from the armor; 8 - fragments of arrowheads (after: [Savenko, 2010, fig. 3; 6]).

$I I$ - Vysochino II, kurgan 11, burial 1. 5 - plan of burial. Grave goods: 1 - cone; 2 - bronze bowler with remnants of cloth;

3 - tip of the spear (peak); 4 - iron plates; 5 - plates from the armor; 6, 10-11 - bone linings on the quiver;

7 - umbon of shield; 8 - beads; 9 - finial (vorvorka); 12,14 - nails from iron details the coffin; 13, 17, 19 - buckles;

15 - harnesses fastening; 16 - hook of the quiver; 19 - arrowheads; 21 - bone linings of the saddle (after: [Bespalyy, Lukyashko, 2008, tab. XXVIII-XXIX]) 


\section{СПИСОК ЛИТЕРАТУРЫ}

Акматов К. Т., Табалдиев К. Ш., 2017. Погребения под овальной каменной насыпью на Тянь-Шане и некоторые вопросы изучения средневековых монгольских погребальных комплексов // Вестник НГУ. Серия: История, филология. Т. 16, вып. 5 : Археология и этнография. С. 68-81.

Бадмаев А. А., 2015. Баранья лопатка в обрядовой практике бурят // Вестник НГУ. Серия: История, филология. Т. 14, вып. 7 : Археология и этнография. С. 255-264.

Бартольд В. В., 1966. К вопросу о погребальных обрядах у турков и монголов // Сочинения. T. IV. М. : Наука. C. $377-396$.

Беспалый Е. И., Лукьяшко С. И., 2008. Древнее население междуречья Дона и Кагальника. Курганный могильник у с. Высочино. МИА Юга России. Т. 1. Ростов н/Д : ЮНЦ РАН. 224 с.

Газимзянов И. Р., Дрёмов И. И., 2020. Погребение с северной ориентировкой на мусульманском могильнике в Болгаре и проблема интерпретации железных конусов // Поволжская археология. № 4 (34). С. 170-184. DOI: https://doi.org/10.24852/pa2020.4.34.170.184.

Дворниченко В. В., Смирнов А. С., Фёдоров-Давыдов Г. А., 1976. Отчет о раскопках курганов в Астраханской области в 1976 г. // Архив ИА РАН. Р-1. № 6719, 6719в.

Дрёмов И. И., 2019. О назначении конусов из листа железа в золотоордынских погребениях // Археология как жизнь. Памяти Евгения Павловича Мыськова. Волгоград : Сфера. С. 250-259.

Жуковская Н. Л., 1989. Два культовых объекта в северной Монголии // Новое в этнографии : (Полевые исследования). Вып. 1. М. : Наука. С. 160-171.

Иванов В. А., 2019. Монголы в составе кочевников Улуса Джучи (Золотой Орды): по данным археологии // Золотоордынское обозрение. Т. 7, № 4. С. 636-651. DOI: http://dx.doi.org/10.22378/2313-6197.2019-74.636-651.

Именохоев Н. В., 1992. Раннемонгольская археологическая культура // Археологические памятники эпохи средневековья в Бурятии и Монголии. Новосибирск : Наука. С. 23-48.

Ковпаненко Г. Т., Гаврилюк Н. А., Евдокимов Г. Л., 2005. Курганы у села Ковалевка (группа IV) // Археологичні дослідження в Украіні 2003-2004 pp. Вип. 7. Киів : ІА НАНУ ; Запоріжжя : Дике поле. С. 363-388.

Козлов П. К., 1949. Путешествие в Монголию. 1923-1926. Дневники, подготовленные к печати Е. В. Козловой. М. : ГИГЛ. $237 \mathrm{c}$.

Круглов Е. В., 2003. Печенеги и огузы: некоторые проблемы археологических источников // Степи Европы в эпоху средневековья. Т. 3. Донецк : ДонНУ. С. 13-82.

Курганный могильник Клин I. URL: http://rosarheolog.ru/kurgannyj-mogilnik-klin-1-kurgan-1 (дата обращения: 21.04.2021).

Ларенок В. А., 1992. Об этнической принадлежности погребенных в средневековых курганах у х. Семёнкин // Донские древности. Вып. 1. Азов : Азов. краевед. музей. С. 158-189.

Мамонтов В. И., Ситников А. В., 1998. Курганный могильник у хутора Сенной // Древности Волго-Донских степей. Вып. 6. Волгоград : Изд-во ВолГУ. С. 113-123.

Мыськов Е. П., 2015. Кочевники Волго-Донских степей в эпоху Золотой Орды. Волгоград : Изд-во Волгогр. фил. ФГБОУ ВО РАНХиГС. 484 с.

Мэнэс Г., 1992. Материалы по традиционной похоронной обрядности захчинов МНP конца XIX - начала XX в. // Традиционная обрядность монгольских народов. Новосибирск : Наука. С. 112-127.

Ользеева С. 3., 2012. Калмыцкие народные традиции. Элиста : ННП «Джангар». 479 с.

Плетнёва С. А., 1958. Печенеги, торки и половцы в южнорусских степях // Труды Волго-Донской археологической экспедиции. Т. І. МИА. Т. 62. М. ; Л. : Изд-во АН СССР. С. 151-226.

Плетнёва С. А., 1962. Половецкие погребения в урочище Каменная балка // Археологические раскопки на Дону. Ростов н/Д : Изд-во Ростов. ун-та. С. 133-137.

Потёмкина Т. М., 2012. Металлические посудовидные изделия из погребений номадов золотоордынского времени Восточной Европы: проблемы и стереотипы // Степи Европы в эпоху средневековья. Т. 11. Донецк : ДонНУ. С. 279-305.

Савенко С. Н., 2010. Позднекочевническое ритуальное захоронение на Ставрополье // Российская археология. №2. C. $147-155$. 
Семби М. К., 2013. Память земли тюрко-монгольской: истоки и символика топонимов (Тюркский меридиан) // Труды КазНИИК. Т. 1. Алматы : КазНИИК. 296 с.

Смирнов П. А., 1999. Путевые записки по Калмыцким степям Астраханской губернии. Элиста : Калм. кн. изд-во. 248 с.

Содномпилова М. М., 2009. Мир в традиционном мировоззрении и практической деятельности монгольских народов. Улан-Удэ : БНЦ СО РАН. 366 с.

Супруненко О. Б., Маєвська С. В., Артем’єв А. В., Горбенко С. О., 2006. Кургани з похованнями золотоординського часу поблизу Волошиного у пониззі Псла. Старожитності околиць Комсомольська. Т. III. Київ ; Полтава : ПП Друкарня «Гротеск».140 с.

Табалдиев К. Ш., 2013. Традиции, связанные с животными, в погребальной практике кочевников Тяньшаня // Вестник НГУ. Серия: История, филология. Т. 12, вып. 3 : Археология и этнография. Новосибирск. C. $157-167$.

Улийбаяр С., Наваан Д., Эрдэнэ М., 2010. Захоронения Тавантолгойской культуры восточной Монголии // Известия лаборатории древних технологий. Вып. 8. С. 211-234.

Усманова Э. Р., Дрёмов И. И., Панюшкина И. П., 2020. Этнокультурный код воинских формирований Улуса Джучи (по археологическим свидетельствам могильника Карасуыр, Улытау) // Джучи : личность, эпоха, память. Алматы. С. 184-217.

Фёдоров-Давыдов Г. А., 1966. Кочевники Восточной Европы под властью золотоордынских ханов. Археологические памятники. М. : МГУ. 276 с.

Фёдоров-Давыдов Г. А., 1984. Кочевнический курган XIV века из Нижнего Поволжья (некоторые особенности погребального обряда средневековых кочевников) // Вопросы древней истории Южной Сибири. Абакан : Хакас. НИИЯЛИ. С. 98-108.

Шалобудов В. Н., Кудрявцева И. В., 1980. Кочевнические погребения Среднего Приорелья // Курганы Степного Поднепровья. Днепропетровск : Днепропетр. гос. ун-т. С. 90-97.

Шараева Т. И., 2011. Обряды жизненного цикла калмыков ХІХ - начала ХХ в. Элиста : НПП «Джангар». 223 с.

\section{REFERENCES}

Akmatov K.T., Tabaldiev K.Sh., 2017. Pogrebeniya pod oval'noy kamennoy nasyp'yu na Tyan'-Shane i nekotorye voprosy izucheniya srednevekovyh mongol'skih pogrebal'nyh kompleksov [Burials Under Oval-Shaped Stone Mounds in Tien Shan and Some Issues of Studying Medieval Mongolian Burial Complexes]. Vestnik NGU. Seriya: Istoriya, filologiya: Arheologiya i etnografiya [Vestnik NSU. Series: History and Philology: Archaeology and Ethnography], vol. 16, iss. 5, pp. 68-81.

Badmaev A.A., 2015. Baran'ya lopatka v obryadovoy praktike buryat [Lamb Shoulder in the Ritual Practice of the Buryats]. Vestnik NGU. Seriya: istoriya, filologiya: Arheologiya i etnografiya [Vestnik NSU. Series: History and Philology: Archaeology and Ethnography], vol. 14, iss. 7, pp. 255-264.

Bartol'd V.V., 1966. K voprosu o pogrebal'nyh obryadah u turkov i mongolov [The Problem of Studying Funeral Rites of Turks and Mongols]. Sochineniya [Essays], vol. IV. Moscow, Nauka Publ., pp. 377-396.

Bespalyy E.I., Luk'yashko S.I., 2008. Drevnee naselenie mezhdurech'ya Dona i Kagal'nika. Kurgannyy mogil'nik u s. Vysochino [Ancient Population of the Lower Don i Kagal'nik. Burial Mound "Vysochino"]. Materialy i issledovaniya po Arkheologii Yuga Rossii, vol. 1. Rostov-na-Donu, SSC RAS. 224 p.

Gazimzyanov I.R., Dremov I.I., 2020. Pogrebenie s severnoy orientirovkoy na musul'manskom mogil'nike v Bolgare i problema interpretacii zheleznyh konusov [Nord-Oriented Burial on the Muslim Burial Ground in Bulgar and the Issue of Interpretation of Iron Cones]. Povolzhskaya arheologiya [The Volga River Region Archaeology], no. 4 (34), pp. 170-184. DOI: https://doi.org/10.24852/pa2020.4.34.170.184.

Dvornichenko V.V., Smirnov A.S., Fedorov-Davydov G.A., 1976. Otchet o raskopkah kurganov v Astrahanskoy oblasti v 1976 g. [Report On Excavations of Kurgans in Astrakhan Region in 1976]. Arhiv IA RAN. R-1, no. $6719,6719 \mathrm{~b}$.

Dremov I.I., 2019. O naznachenii konusov iz lista zheleza v zolotoordynskih pogrebeniyah [On the Appointment of Cones from a Sheet of Iron in the Burials of Golden Horde]. Arheologiya kak zhizn'. Pamyati Evgeniya Pavlovicha Mys'kova [Archaeology as Life. In Memory of Evgeny Pavlovich Myskov]. Volgograd, Sfera Publ., pp. 250-259. 
Zhukovskaya N.L., 1989. Dva kul'tovyh ob'ekta v severnoy Mongolii [Two Cult Sites in Northern Mongolia]. Novoe v etnografii (Polevye issledovaniya) [New in Ethnography (Field Investigations)], iss. 1. Moscow, Nauka Publ., pp. 160-171.

Ivanov V.A., 2019. Mongoly v sostave kochevnikov Ulusa Dzhuchi (Zolotoy Ordy): po dannym arheologii [Mongolian Nomads in The Ulus Of Jochi (Golden Horde) According to Archaeological Materials]. Zolotoordynskoe obozrenie [Golden Horde Review], vol. 7, no. 4, pp. 636-651. DOI: http://dx.doi.org/10.22378/ 2313-6197.2019-7-4.636-651.

Imenohoev N.V., 1992. Rannemongol'skaya arheologicheskaya kul'tura [Early Mongolian Archaeological Culture]. Arheologicheskie pamyatniki epohi srednevekov'ya v Buryatii i Mongolii [Archaeological Sites of the Middle Ages in Buryatia and Mongolia]. Novosibirsk, Nauka Publ., pp. 23-48.

Kovpanenko G.T., Gavrilyuk N.A., Evdokimov G.L., 2005. Kurgany u sela Kovalevka (gruppa IV) [Kurgans at Village Kovalevka (Group IV)]. Arheologichni doslidzhennya v Ukraini 2003-2004 rr. [Archaeological Research in Ukraine 2003-2004], iss. 7. Kiiv, IA NANU, Zaporizhzhya, Dikoe pole Publ., pp. 363-388.

Kozlov P.K., 1949. Puteshestvie v Mongoliyu. 1923-1926. Dnevniki, podgotovlennye k pechati E.V. Kozlovoy [Travel to Mongolia. 1923-1926. Diaries Prepared for Printing by E.V. Kozlova]. Moscow, GIGL Publ. 237 p.

Kruglov E.V., 2003. Pechenegi i oguzy: nekotorye problemy arheologicheskih istochnikov [Pecheneg and Oguz Tribes: Some Problems of Archaeological Sources]. Stepi Evropy v epohu srednevekov'ya [Steppes of Europe in the Middle Ages], vol. 3. Donetsk, DonNU, pp. 13-82.

Kurgannyy mogil'nik Klin I[Kurgan Cemetery Klin I]. URL: http://rosarheolog.ru/kurgannyj-mogilnik-klin-1-kurgan-1/ (accessed 21 April 2021).

Larenok V.A., 1992. Ob etnicheskoy prinadlezhnosti pogrebyonnyh v srednevekovyh kurganah u h. Semyonkin. [On the Ethnicity of those Buried in Medieval Kurgans about Hutor Semyonkin]. Donskie drevnosti [Antiquities of the Don], iss. 1. Azov, Azov Museum of Local Lore, pp. 158-189.

Mamontov V.I., Sitnikov A.V., 1998. Kurgannyy mogil'nik u hutora Sennoy [Kurgan Cemetery at Hutor Sennoy]. Drevnosti Volgo-Donskih stepey [Antiquities of the Volga-Don Steppes], iss. 6. Volgograd, VolSU, pp. 113-123.

Mys'kov E.P., 2015. Kochevniki Volgo-Donskih stepey v epohu Zolotoy Ordy [Nomads of Volgo-Don Steppes at Golden Horde Epoch]. Volgograd, Volgograd branch of RANEPA. $484 \mathrm{p}$.

Menes G., 1992. Materialy po traditsionnoy pohoronnoy obryadnosti zahchinov MNR kontsa XIX - nachala XX v. [Materials on the Traditional Funeral Rites of Zakhchin MNR in the Late $19^{\text {th }}$ and Early $20^{\text {th }}$ Centuries]. Traditsionnaya obryadnost'mongol'skih narodov [Traditional Rite of the Mongolian Peoples]. Novosibirsk, Nauka Publ., pp. 112-127.

Ol'zeeva S.Z., 2012. Kalmytskie narodnye traditsii [Folk Traditions of Kalmyks]. Elista, NNP «Dzhangar» Publ. 479 p.

Pletneva S.A., 1958. Pechenegi, torki i polovcy v Yuzhno-Russkih stepyah [Pechenegs, Torks and Cumans in the Steppes of South Russian]. Trudy Volgo-Donskoy arkheologicheskoy ekspeditsii [Proceedings of the VolgaDon Archaeological Expedition], vol. I. Materialy i issledovaniya po Arkheologii SSSR, vol. 62. Moscow, Leningrad, USSR Academy of Sciences, pp. 151-226.

Pletneva S.A., 1962. Polovetskie pogrebeniya v urochishche Kamennaya balka [Cumans Burials in the Tract Kamennaya Balka]. Arheologicheskie raskopki na Donu [Archaeological Excavations in the Don Region]. Rostov-na-Donu, Rostov University, pp. 133-137.

Potemkina T.M., 2012. Metallicheskie posudovidnye izdeliya iz pogrebeniy nomadov zolotoordynskogo vremeni Vostochnoy Evropy: problemy i stereotipy [Metal Tableware-Like Products From Burials of Nomads of Golden Horde Time of Eastern Europe: Problems And Stereotypes]. Stepi Evropy v epohu srednevekov'ya [Steppes of Europe in the Middle Ages], vol. 11. Donetsk, DonNU, pp. 279-305.

Savenko S.N., 2010. Pozdnekochevnicheskoe ritual'noe zahoronenie na Stavropol'e [Late Nomadic Ritual Burial in Stavropol Region]. Rossiyskaya arkheologiya [Russian Archaeology], no. 2, pp. 147-155.

Sembi M.K., 2013. Pamyat' zemli tyurko-mongol'skoy: istoki i simvolika toponimov (Tyurkskiy meridian) [Memory of the Land Turkic-Mongolian: the Origins and Symbolism of Place Names (Turkish Meridian)]. Trudy KazNIIK [Proceedings of Kazakh Cultural Research Institute], vol. 1. Almaty, KazCRI. 296 p.

Smirnov P.A., 1999. Putevye zapiski po Kalmytskim stepyam Astrahanskoy gubernii [Notes of Travel on the Kalmyk Steppes in Astrakhan Province]. Elista, Kalmytskoe knizhnoe izdatel'stvo Publ. 248 p. 
Sodnompilova M.M., 2009. Mir v traditsionnom mirovozzrenii i prakticheskoy deyatel'nosti mongol'skih narodov [World in the Traditional Worldview and Practical Actions of Mongolian Peoples]. Ulan-Ude, Research Center Buryat of the Siberian Branch of the Russian Academy of Sciences. $366 \mathrm{p}$.

Suprunenko O.B., Maevskaya S.V., Artem'ev A.V., Gorbenko S.O., 2006. Kurgani z pohovannyami zolotoordins'kogo chasu poblizu Voloshinogo u ponizzi Psla [Kurgans with Burials of the Golden Horde Period Near Voloshino at the Mouth of the Psel]. Starozhitnosti okolits' Komsomol's'ka [Antiquities of the Komsomolska Area], vol. III. Kiïv, Poltava, PP Drukarnya «Grotesk». 140 p.

Tabaldiev K.Sh., 2013. Traditsii, svyazannye s zhivotnymi, v pogrebal'noy praktike kochevnikov Tyan'shanya [Traditions with Animals in Burials of Tien-Shan Nomads]. Vestnik NGU. Seriya: Istoriya, filologiya: Arheologiya i etnografiya [Vestnik NSU. Series: History and Philology: Archaeology and Ethnography], vol. 12, iss. 3, pp. 157-167.

Uliybayar S., Navaan D., Erdene M., 2010. Zahoroneniya Tavantolgoyskoy kul'tury vostochnoy Mongolii [Graves of Tavantolgoi Culture Of Eastern Mongolia]. Izvestiya laboratorii drevnih tekhnologiy [Reports of the Laboratory of Ancient Technologies], iss. 8, pp. 211-234.

Usmanova E.R., Dremov I.I., Panyushkina I.P., 2020. Etnokul'turnyy kod voinskih formirovaniy Ulusa Dzhuchi (po arheologicheskim svidetel'stvam mogil'nika Karasuyr, Ulytau) [Ethnocultural Code of Military Groups at Ulus Jochi from Archeology of the Karasuyr Burial Site, Ulytau, Central Kazakhstan]. Djuchi: lichnost', epoha, pamyat' [Jochi: Personality, Epoch, Memory]. Almaty, pp. 184-217.

Fedorov-Davydov G.A., 1966. Kochevniki Vostochnoy Evropy pod vlast'yu zolotoordynskih hanov. Arheologicheskie pamyatniki [Nomads of the East Europe under the Reign of Golden Horde Khans. Archaeological Monuments]. Moscow, MSU. 276 p.

Fedorov-Davydov G.A., 1984. Kochevnicheskiy kurgan XIV veka iz Nizhnego Povolzh'ya (nekotorye osobennosti pogrebal'nogo obryada srednevekovyh kochevnikov) [Nomadic Kurgan of $14^{\text {th }}$ Century from the Lower Volga Region (Some Features of the Burial Rite of Medieval Nomads)]. Voprosy drevney istorii Yuzhnoy Sibiri [Issues of the Ancient History of Southern Siberia]. Abakan, Khakass Research Institute of Language, Literature and History, pp. 98-108.

Shalobudov V.N., Kudryavtseva I.V., 1980. Kochevnicheskie pogrebeniya Srednego Priorel'ya [Burials of Nomadic of the Middle Orel Region]. Kurgany Stepnogo Podneprov'ya [Kurgans of the Steppe Dnieper Region]. Dnepropetrovsk, Dnepropetrovsk State University, pp. 90-97.

Sharaeva T.I., 2011. Obryady zhiznennogo tsikla kalmykov XIX-nachala XXv. [Rituals of Life Cycle of Kalmyks of the $19^{\text {th }}$ and Early $20^{\text {th }}$ Centuries]. Elista, NPP «Dzhangar» Publ. $223 \mathrm{p}$.

\section{Information About the Authors}

Igor I. Dremov, Candidate of Sciences (History), Archaeologist, Regional Center for Ecology, Local Studies and Tourism, Novouzenskaya St, 156, 410054 Saratov, Russian Federation, iid57@yandex.ru, https://orcid.org/0000-0002-8525-1874

Evgeniy V. Kruglov, Secretary, Volgograd Regional Branch of the All-Russian Society for Protection of Monuments of History and Culture, Prosp. Lenina, 86, Office 502, 400005 Volgograd, Russian Federation, khasar@vlpost.ru, https://orcid.org/0000-0002-7070-9889

\section{Информация об авторах}

Игорь Иванович Дрёмов, кандидат исторических наук, археолог, Областной центр экологии, краеведения и туризма, ул. Новоузенская, 156, 410054 г. Саратов, Российская Федерация, iid57@yandex.ru, https://orcid.org/0000-0002-8525-1874

Евгений Викторович Круглов, секретарь, Волгоградское региональное отделение «Всероссийского общества охраны памятников истории и культуры», просп. им. В.И. Ленина, 86, оф. 502, 400005 г. Волгоград, Российская Федерация, khasar@vlpost.ru, https://orcid.org/0000-0002-7070-9889 